\title{
Labor Market Discrimination During Post-Communist Transition: A Monopsony Approach to the Status of Latvia's Russian Minority
}

\author{
By: Robert S. Chase
}

Working Paper No. 381

September 2000 


\title{
LABOR MARKET DISCRIMINATION DURING POST-COMMUNIST TRANSITION:
}

\section{A Monopsony Approach to the Status of Latvia's Russian Minority}

\author{
Robert S. Chase* \\ Johns Hopkins University-SAIS \\ William Davidson Institute of Transition Economics
}

Draft: September 2000

* Robert Chase is Assistant Professor of International Economics at Johns Hopkins UniversitySAIS and Research Fellow at the William Davidson Institute of Transition Economics at the University of Michigan. The author thanks Paul Schultz, Jennifer Hunt, Branko Milanovic, Will Dow, Judy Dean and Brian Burgoon for comments, the Central Statistics Office of the Republic of Latvia for their insights and for making the data available to me, and Irina Klitchnikova and Sylvia Zucchini for valuable research assistance. I am wholely responsible for all errors. 


\title{
LABOR MARKET DISCRIMINATION \\ DURING POST-COMMUNIST TRANSITION:
}

\section{A Monopsony Approach to the Status of Latvia's Russian Minority}

\begin{abstract}
Conventional wisdom suggests that during communism, tastes for discrimination were suppressed. In partial explanation for ethnic tensions observed following central planning, economic liberalization allows those tastes to be expressed. This paper explores the feasibility of monopsony as an economic structure supportive of discrimination during transition, using Latvia's ethnic Russians as a case study. Measuring employment concentration and earnings differentials across regions, monopsony appears prevalent in the country. A monopsony explanation requires Russians to have lower labor supply elasticity than Latvians, a condition which estimates for participation probability confirm. Earnings decompositions show that though Russians are paid more than Latvians on average, given their human capital characteristics, they suffer earnings discrimination of between 5.5 and 7.3 percent. In addition, compared with Latvians the likelihood that Russians will be unemployed is greater, though Russians are less likely to register for unemployment services. This evidence suggests that the lack of integrated, flexible labor markets in Latvia, and the monopsony which results, have supported labor market discrimination against Russians during transition.
\end{abstract}

\section{INTRODUCTION}

In Central and Eastern Europe, political events suggest ethnic tension accompanies economic transition. From the violent dissolution of Yugoslavia to questions about minority citizenship rights in the Baltic states, disputes based on ethnicity appear more prevalent since central planners no longer officially pronounce the shared interests of all workers. If the strictures of central planning suppressed the expression of many tastes, excess demand for those tastes were likely pent-up. One of the prime benefits of economic liberalization is that it allows people to act according to their preferences. However, conventional wisdom suggests that ethnic tension has erupted following communism largely because majority populations express their tastes for 
discrimination against minorities. A comprehensive examination of ethnic tension would naturally invoke historical, sociological and political insights. This paper will focus on what economics can offer a discussion of these issues. Specifically, it will consider the relation between earnings discrimination and imperfectly competitive market structures during transition.

A well-developed literature discusses the theory of discrimination in market-based economies. Classic work (Becker (1957)) frames the problem in terms of prejudicial tastes. In a perfectly competitive market, employers with such tastes would pay for them with lower profits. In the long-term, market forces would eliminate discriminating firms. This approach based on perfect competition and tastes for discrimination dominates the literature. However, it likely has limited applicability to analysis of post-Communist ethnic tension in the short term, where perfect competition obtains only in very limited situations.

Absent perfect competition, an alternative branch of the literature outlines how discrimination can be sustained. Building on Robinson (1934), it concentrates on how monopsony allows wage discrimination, defined as payment below labor's marginal revenue product. In monopsony, single buyers offer wages below the worker's marginal revenue product, which could account for discrimination against certain groups. However, industrial country empirical evidence has not supported the monopsony model as a central explanation for wage discrimination. Monopsony is unlikely to prevail in these settings and estimated labor supply elasticities run counter to this model's stipulations.

In contrast to industrialized countries, post-communist economies exhibit characteristics appropriate to a monopsony explanation for discrimination. A caricature of central planning would portray the economy as having a single employer, the state. While the comparative systems literature suggests that labor markets were much more competitive under Communism 
than this extreme (see Bergson (1944) for a classic presentation), many local labor markets were dominated by single large firms introduced and maintained by central-planners. These firms would likely enjoy local monopsony power. During Communism restrictions on mobility within the country would reinforce these monopsonies.

Historical monopsonies likely persist through transition. While new firms eventually enter isolated labor markets, the pace at which monopsonies disband is slow and erratic, particularly given regional disparities in investment and growth following Communism. In addition, official measures, such as continued geographic restrictions on workers' movement, and structural problems, such as inadequately developed housing markets, limit mobility into and out of segmented labor markets. As a result of these institutional factors, the monopsony explanation might have particular resonance for an analysis of post-Communist labor market discrimination.

This paper will examine labor market discrimination during post-Communist transition, taking as a case study Latvia and its ethnic Russian minority. It will examine indicators of monopsony prevalence in Latvia. Since labor supply elasticity is central to the monopsony approach and its applicability, the paper will estimate labor supply elasticities across ethnic groups, ascertaining whether the group proportedly discriminated against has lower elasticity. Having established that a monopsony approach is potentially relevant, it will test for earnings differentials across groups that cannot be explained by factors directly related to productivity using classic decomposition techniques developed by Oaxaca (1973). Moving beyond wage discrimination, it will consider differences in unemployment across groups. Comparisons of ILO standard unemployment rates and officially reported unemployment rates, which are based on registration for benefits, suggest that official statistics underrepresent ethnic differences. To isolate possible ethnicity bias in unemployment and registration, the paper then analyzes the 
probability of becoming unemployed and of registering for benefits, correcting for observed characteristics.

The analysis proceeds as follows. Section II reviews the literature on discrimination and on labor markets during transition. Section III presents a model of discrimination based on monopsony and describes the paper's empirical strategy. Section IV summarizes empirical results concerning the viability of a monopsony approach to wage and unemployment bias against Latvia's Russians. Section V concludes.

\section{LITERATURE REVIEW}

Economics defines discrimination as paying workers less than their marginal product based on characteristics with no relation to productivity. A well-developed theoretical literature presents two central approaches to analyzing wage discrimination, The more prevalent strand builds on Becker (1957), which established a framework of tastes for discrimination. With perfect competition and differing degrees of prejudicial tastes, employers with the least tastes for discrimination hire members of the minority group, paying them lower wages than equally wellqualified non-minorities. As payment for their tastes, these employers enjoy higher profits than those with greater taste for discrimination. Over time, profit-seeking capital increases the productive capacity and employment of the least prejudicial firms. Tastes for discrimination tend to disappear with bankruptcy for those with discriminatory tastes and the entry of entrepreneurial employers seeking profits arising from less prejudice. According to this framework, tastes for discrimination and lower wages for minority groups could persist where firm entry and entrepreneurial skills are inelastically supplied, both characteristics that likely obtain during postcommunist transition. 
Another branch of research discusses the potential for discrimination absent perfect competition. Robinson (1934) presented the classic model of monopsony and discrimination: with the ability to set prices, a single buyer of labor can offer wages below workers' marginal product. Madden (1973) updated and summarizes this approach, though Cain (1986) discusses its empirical difficulties. If monopsony is to generate lower wages for discriminated groups, those groups should have lower labor supply elasticity. But evidence suggests that, even though holding productivity constant US women are less-well paid, they have higher elasticity. Moreover, labor market integration has diminished the prevalence of monopsony in the US, while measured discrimination continues.

Despite these difficulties, Sharir (1995) evaluates how the literature has put less emphasis on the monopsony approach to gender discrimination than the approach merits. Several authors have considered monopsony in specific labor markets. Using historical evidence, Fishback (1998) relies upon monopsony to analyze American labor markets in the early 1900s. Ransom (1993) explores university monopsony power to discuss payments to seniority in academia.

More recent theoretical work seeks to expand upon the monopsony and Beckerian taste approaches to discrimination. Kolpin and Singell (1997) rely upon asymmetric information to describe the possibility of discrimination, while Naylor (1996) attribute it to asymmetric collusion in the presence of employer power. Gottfries and McCormick (1995) consider the link between discrimination and unemployment by focusing on segmented labor markets.

If the theoretical work on discrimination presents competing approaches, empirical work to measuring the degree of wage discrimination is based primarily on Oaxaca (1973) or elaborations thereon. As described in Section III below, this approach decomposes wage 
differences into those attributable to measurable human capital factors and those due to discrimination based on gender or ethnicity.

The empirical microeconomic literature on labor markets in transition economies considers changing wage structures during and after communism and the effects on unemployment of labor market support policies. For example, Brainard (1998) analyzes the winners and losers from the early years of Russia's economic transition, decomposing the wage effects of human capital and unmeasured skill for men and women. Chase (1998) compares earnings information during Communism and that from early transition in the Czech Republic and Slovakia, making use of the split of these two previously joined republics to link the rapidity of transition policies to changed wage structures.

While these papers consider the gender earnings differentials and find them to be increasing with time, little research directly considers earnings discrimination by ethnicity in transition economies. One exception is Kroncke and Smith (1999), who evaluate the degree of earnings discrimination against Russians in Estonia. Using classic decomposition techniques, they find no evidence of discrimination against Russians in 1989 but significant discrimination in 1994. However, Kroncke and Smith (1999) do not explicitly relate economic characteristics prevalent following central planning to explain this wage discrimination.

\section{THEORY AND EMPIRICAL APPROACH}

\section{Monopsony and Discrimination}

Approaching ethnic discrimination primarily based upon monopsony, it is useful to review the theory of how this market structure leads workers of one ethnic group to be paid less than their marginal product. A profit maximizing monopsonist hires labor until workers' marginal product and marginal factor cost are equal. Her monopsony power allows her to pay wages 
below this marginal factor cost. Wage discrimination results, though its extent depends inversely upon labor supply elasticity.

Somewhat more formally, in a given labor market the monopsonist faces the upwardsloping labor supply $L(w)$ with elasticity $\varepsilon$. If the inverse labor supply is $w(L)$, its first derivative with respect to $L, w^{\prime}(L)$ will be inversely proportional to $\varepsilon$. Given total factor cost of labor which is $T F C=w(L) L$, marginal factor cost is $M F C=w^{\prime}(L) L+w(L)$. The cost-minimizing monopsonist will hire labor $L^{*}$ such that the value of the marginal product of labor (VMP) equals the marginal factor cost $(M F C)$.

$$
\text { [1] } \quad V M P=M F C=w^{\prime}\left(L^{*}\right) L^{*}+w^{*}\left(L^{*}\right)
$$

Monopsony power allows the firm to offer a wage below the VMP. The degree of difference depends on:

[2] $\quad V M P-w^{*}\left(L^{*}\right)=w^{\prime}\left(L^{*}\right) L^{*}$

Because w'(L) is inversely proportional to labor supply elasticity as the derivative of the inverse labor supply curve, the smaller the elasticity of labor supply $\varepsilon$, the greater the difference between $V M P$ and the offered wage and the greater the wage discrimination.

\section{Measuring Monopsony}

To apply a monopsony approach to ethnic discrimination following communism, it is important to establish the existence of monopsony in local labor markets. Several institutional factors suggest that individual buyers of labor might exercise monopsony power in specific labor markets and that workers cannot move easily to other labor markets. Throughout transition economies, large regional disparities in unemployment exist (e.g., Ham, Svejnar, and Terrell (1998) analyze the disparities in the Czech Republic). Where single industries dominated labor markets during central planning, during transition a limited number of firms likely dominating 
Latvia's local labor markets. These communist-era firms, or those that succeeded them during privatization, would likely still exercise monopsony power.

If workers can move to other labor markets, then a single dominant demander of labor need not indicate monopsony. Several facets of Latvia's transition hinder labor mobility. Officially, workers need to have a stamp in their internal passbooks designating where they are allowed to live and work. While these stipulations might not bind universally, their existence points to limitations on labor mobility. Further, because the Latvian housing market has not been privatized, it is difficult for workers interested in moving to different areas to find permanent accomodation. Latvian monopsonies likely persist given the continuing existence of dominant employers in local labor markets and of constraints on local mobility.

Seeking empirical evidence of Latvian monopsony, the paper explores two alternative indicators, one direct based on employment concentration, the other indirect based on regional wage differentials. To exercise monopsony power, a firm must face few other competitors for labor in local markets. Labor markets where most workers are employed by a limited number of firms are potentially monopsonistic. The paper first presents evidence on employment concentration, defined by the percentage of workers in local labor markets who are employed in specific industries.

For monopsonistic labor markets to exist, there must be restrictions on labor mobility that keep workers from moving to areas with other employers that offer non-discriminatory wages. In an integrated labor market, after correcting for all other individual characteristics, the location of ones job should not influence wages: those differences should be arbitraged away. The magnitude of the regional disparities, as measured by coefficients on regional dummies, indicates the degree to which individual labor markets are segmented, and by extension, the degree of monopsony 
prevalent in different geographic areas. While some of those regional wage differences will reflect alternative costs of living, in the absence of labor mobility, real earnings differences will persist, after correcting for human capital characteristics.

As an indirect indicator of monopsony in Latvia, we analyze the structure of earnings in the Latvian labor market. Using data on earnings and human capital characteristics, the paper presents ordinary least squares regressions on log earnings following Mincer (1974), including in the analysis regional indicator variables.

$$
\text { [3] } L n W_{i}=\alpha+\beta X_{i}+\delta R_{i}+\varepsilon_{i}
$$

Because of a broad human capital literature which has established their different earnings structures, men and women are treated separately. The aggregate wage effects $\delta$ of region $R$ provide an indicator of the degree of monopsony in Latvia.

Beyond allowing this measure of regional disparity, these earnings regressions serve a second function. With information about earnings structure and individual characteristics (education, age, gender, nationality, etc.), we have an estimate of the returns to different observed characteristics in the labor market. With this information about payments to these observable traits, we can predict the wages of all people, regardless of whether they actually worked. These predicted earnings are useful for analyzing the effect of offered wages on labor supply and unemployment.

\section{Measuring Relative Labor Supply Elasticities}

To use a monopsony approach to discrimination, one must establish not only the existence of monopsony, but also test whether the group purportedly discriminated against has lower labor supply elasticity than the majority group. Based on predicted earnings, we obtain estimates of 
labor supply elasticity. Because of data difficulties measuring continuous labor supply indicators such as hours worked, the more discrete measure of labor force participation is used. Elasticities result from the probit coefficient on (predicted) earnings. The probit estimate takes the form:

$$
\text { [4] } \operatorname{Pr}\left(S_{i}\right)=\Phi\left(\alpha+\gamma \bar{W}_{i}+\beta Z_{i}+\varepsilon_{i}\right)
$$

where the coefficient $\beta$ is taken as an estimate of the labor supply elasticity. Interaction terms for those of Russian ethnicity establish the relative earnings elasticity of this group with respect to the Latvian majority.

\section{Oaxaca Earnings Decomposition}

Through a careful decomposition of these earnings differences based on Oaxaca (1973), we consider the sources and degree of earnings discrimination in the Latvian economy. Using earnings regressions in a form presented in [3], though stratifying this data not by gender but by ethnicity, we can establish the geometric mean earnings for Latvians and Russians:

[5] $\bar{W}_{L}=\beta_{L} \bar{X}_{L}$ and $\bar{W}_{R}=\beta_{R} \bar{X}_{R}$

The gross (unadjusted) logarithmic wage differential results from the difference between these geometric mean wages by group:

[6] $\ln \left(\bar{W}_{L}\right)-\ln \left(\bar{W}_{R}\right)=\beta_{L} \bar{X}_{L}-\beta_{R} \bar{X}_{R}$

However, any gross wage differential could be due to differences between the groups' mean level of observable characteristics (such as more experience or more relevant education). If those characteristics allow one group to be more productive than another, then some of this earnings differential can be explained as payments for higher productivity.

In the decomposition analysis, one assumes that some earnings structure represents payments to characteristics based entirely on worker productivity. Each group's actual earnings 
are compared to the earnings they would receive if paid strictly according to this non-

discriminatory measure of productivity. We attribute the difference between actual and predicted earnings to discrimination (in the event that actual earnings are below predicted earnings) or favoritism (in the event that actual earnings are above predicted earnings). Because a prime difficulty is to determine the non-discriminatory earnings structure, most studies treat one group's earnings structure as based strictly on productivity and then test the converse, treating the other group's earnings structure as strictly based on productivity. Because the "true" productivity valuation is assumed to be bracketed between these two extremes, the true index of discrimination should fall between those generated by relying one group's structures.

$$
\text { [7] } \begin{array}{ll}
\ln \left(\bar{W}_{L}\right)-\ln \left(\bar{W}_{R}{ }_{R}\right)=\beta_{L}\left(\bar{X}_{L}-\bar{X}_{R}\right) \\
& \text { or } \\
& \ln \left(\bar{W}^{*}{ }_{L}\right)-\ln \left(\bar{W}_{R}\right)=\beta_{R}\left(\bar{X}_{L}-\bar{X}_{R}\right)
\end{array}
$$

\section{Unemployment differentials}

To augment this analysis of wage differentials, the paper also considers potential bias in unemployment. Many transition economies report unemployment rates based on who registers for unemployment ${ }^{1}$. After comparing unemployment rates across different ethnic groups according to alternative definitions, the study explores the individual characteristics associated with higher probability of being unemployed.

$$
\text { [8] } \operatorname{Pr}\left(U_{i} \mid S\right)=\Phi\left(\alpha+\beta X_{i}+\varepsilon_{i}\right)
$$

\footnotetext{
${ }^{1}$ In fact, much of the literature on unemployment during transition is based on these officially reported figures for unemployment, figures based on administrative data of who registers for benefits. In early transition, these data were all that were available, for ILO standard unemployment figures, based on who is not currently working and has actively looked for a job in the past 14 days, requires extensive labor force survey information. In early transition, the costs of conducting such surveys was prohibitive. However, though many countries including Latvia have collected data allowing ILO standard unemployment statistics to be published, many still offically report the registration-based statistics.
} 
Estimating these parameters allows one to identify the risk factors for unemployment, including gender, education, nationality, and location. Further, the paper estimates equation [8] for alternative definitions of unemployment, i.e., the standard ILO definition versus those indicating who registers as unemployed with the state employment service. The difference offers insight into how a non-standard definition of unemployed masks some aspects of the Latvia's true unemployment situation.

When comparing the marginal effects of different characteristics, the common practice with probit analysis is to present the amount that the probability of an outcome, becoming unemployed in this case, changes with a change in characteristics. These marginal effects need to be reported with respect to some starting-point probability. Convention suggests using the probability estimates for an "average" person as a starting point for these marginal effects, where an average person has characteristics equal to the sample mean. However, it is then difficult to compare marginal effects of characteristics across different samples. Because samples have different probabilities at their means, slopes are evaluated at different starting points on a nonlinear cumulative density function. Marginal effects are difficult to compare.

To facilitate comparison of marginal effects across different groups with different base probabilities, this analysis evaluates all the marginal effects based on a common starting point on the normal cumulative density function. It establishes one group's probability of being unemployed as the standard. Then, marginal effects of different characteristics are calculated from that same point on the CDF. For continuous variables, the marginal difference is:

$$
\text { [9] } \frac{\partial \operatorname{Pr}\left(U_{c} \mid S\right)}{\partial x_{c}}=\phi\left(\bar{X}_{r} \bar{B}_{r}\right) \cdot \beta_{c}
$$


where $\mathrm{r}$ subscripts stand for the reference group and $\mathrm{c}$ subscripts stand for the comparison group. For discrete variables, the marginal effects with respect to the comparison probability are:

$$
\text { [10] }\left.\Delta \operatorname{Pr}\left(U_{c} \mid S\right)\right|_{x_{c}=1}=\Phi\left(\bar{X}_{r} \bar{B}_{r}-\beta_{r} x_{r}-\beta_{c}\right)-\Phi\left(\bar{X}_{r} \bar{B}_{r}-\beta_{r} x_{r}\right)
$$

While having the detrimental effect of not having each probability calculated according to the actual point on the $\mathrm{CDF}$ which obtains for a given group, this procedure has the benefit of allowing more clear comparisons between the marginal effects of characteristics across groups.

To buttress this analysis of different unemployment definitions, a separate probit sheds light on who of the unemployed according to the ILO definition was also able to register as unemployed with the State Employment Service. Taking those who are unemployed according to the ILO standard as the population, this probit presents information about the factors which increase the probability that an unemployed person registers for benefits.

\section{Data Available}

To carry out this empirical analysis, the study uses three data sources. The Latvian Household Budget Survey (HBS) from the first quarter of $1997^{2}$ is used to analyze the structure of earnings and predict how much people would expect to receive given their personal characteristics and location. When analyzing Latvian labor force participation and unemployment, the paper focuses on Labor Force Survey micro-data from the first quarter of 1998 (LFS 98). To offer some information about trends in these labor market outcomes, the paper compares these 1998 participation and unemployment findings with similar Labor Force Survey data collected in the second quarter of 1996 (LFS 96).

\footnotetext{
${ }^{2}$ I would like to thank Mr. Robert Ackland for extracting a sub-set of the HBS data including information on wages and relevant independent variables.
} 
Table 1 presents descriptive statistics about the primary individual-level variables used in the analysis. Along with information about human capital, marital status and region, Table 1 offers information about nationality. In 1998, the population consists of roughly 62 percent Latvians, 27 percent Russians, and 11 percent people of other nationalities. In 1996, the percentage of Latvians was lower, at roughly 59 percent. Between 1996 and 1998 the share of non-Latvians in the country declined, perhaps because of emigration.

Because the HBS collected different information than the two LFS sources, it is worth drawing attention to difficulties comparing the three data sets presented in Table 1. Because the HBS data is comprised of people reporting non-zero wages from a main job, the 933 women and 914 men are not a random sample of the Latvian population but are selected because they work. As a result, their individual characteristics are not comparable with the respondents from the LFS surveys $^{3}$, which consist of random samples of the whole population.

For example, among people in the HBS who work, the average age is 40 years. In the entire Latvian population, the average age is 47.7 years for women and 43.6 years for men. ${ }^{4}$ Educational attainment is higher in the HBS data (e.g., 25 percent of women have higher education in the HBS data, though only 12 percent do in the LFS 98 data). The HBS and LFS surveys also used different categories to describe educational attainment: the HBS data distinguishes five categories, while the LFS data contains eight. This poses a problem for using the characteristics of the HBS data to predict the earnings of those included in the LFS (the rationale for which is described below). However, for predicting earnings it is possible to collapse the LFS data into five categories comparable to those used in the HBS. Those LFS respondents

\footnotetext{
${ }^{3}$ When one selects from the LFS '98 and LFS '96 only those people who are currently working, the demographic characteristics are roughly comparable to the HBS sample.
} 
who reported having "Secondary Specialized", "Technical Secondary", or "Comprehensive Secondary" education are grouped into the "Secondary Education" category when being compared with the HBS data.

\section{EMPIRICAL FINDINGS}

\section{Monopsony Indicators}

Offering some indication of the prevalence of monopsony in Latvia, Table 2 contains summary statistics about employment concentration. Because of the stipulation that officially one must have a stamp in ones passbook certifying ones ability to live and work in a particular administrative district, for these indicators we consider as a separate labor market each of Latvia's 32 administrative districts ${ }^{5}$. In each of these local labor markets, we tabulate the industry in which workers were employed according to two digit standard industry codes. Table 2 reports the percentage of non-farming workers employed by the most prevalent types of industry.

In the average local Latvian labor market, 48.0 percent of workers are employed by the three most prevalent industries in the district, 36.0 percent work for the two most prevalent, and 21.5 percent for the most prevalent industry. While the average degree of employment concentration is quite high, there is significant dispersion in its concentration across labor markets. For example, in one labor market, 32.7 percent of all workers are employed by the same industry. While difficult evaluate their relative magnitude, these employment concentration figures suggest dominant employers in many local labor markets, employers likely to exercise monopsony power.

\footnotetext{
${ }^{4}$ While the rest of the LFS analysis uses sample weights to ensure that the information represents the Latvian population, these descriptive statistics are unweighted to show the characteristics of the sample itself.

${ }^{5}$ For the purposes of Table 2, all of Riga's administrative districts are collapsed into a single observation, for presumably workers can get to jobs anywhere within the city limits, so that the capital city is a single integrated
} 
Table 3 presents an alternative, indirect method of measuring monopsony in Latvia, based on regional wage differentials. It includes the results of log earnings regressions for men and women as presented in equation [3]. They provide significant evidence for differences in labor markets across Latvia's regions, which supports the contention that Latvia's labor markets are not particularly well-integrated, as one would expect with persistent monopsony ${ }^{6}$. These regional effects are quite distinct between men and women. Compared to rural parts of the country and controlling for all other differences in individual characteristics, earnings in urban areas are 27 percent higher for men and 15 percent higher for women. Over and above this general urban benefit, men working in Riga receive an additional 14 percent wage premium. For women, the Riga labor market offers wages statistically indistinguishable from Latvia's other urban areas. Compared to the Kurzeme region, earnings in Vidzeme and Latgale are significantly less for both men and women. For example, men and women in Latgale receive earnings 26 percent less than in Kurzeme. This is likely due to the particularly difficult economic conditions there.

While some portion of these earnings differentials represents divergent living costs, the magnitude of the differences, particularly in a country as geographically small as Latvia, suggests a significant lack of national labor market integration. This segmentation suggests that monopsony is reasonably prevalent in the economy following the end of central planning.

The earnings regressions also offer insights into earnings structure more generally. Consistent with an extensive human-capital literature, the Latvian labor market rewards those

\footnotetext{
labor market. Apart from the Riga district, the average population of these local labor markets is approximately 50,000 people.

6 The excluded geographic categories are "rural" and "Kurzeme". The "urban" dummy captures the general effect of living in any urban area versus living in rural areas, regardless of region. The regional dummies ("Riga Region", "Vidzeme", "Zemgale" and "Latgale") reflect earnings differences between Kurzeme and these other regions. Finally, the "Riga City" variable is an interaction term between "urban" and "Riga Region", thus
} 
with more education. While the returns to education are generally larger for women than men, in Latvia, the opposite is true. However, consistent with the findings of Chase (1998) for the Czech Republic and Slovakia, the returns to general secondary education are larger than those to vocational education.

The earnings analysis also suggests that after controlling for educational differences and regions, it is possible to discern statistically significant differences only for Russian women, not other non-Latvian groups. While ethnically Russian men and women both receive approximately 7 percent lower earnings than Latvians, ceteris paribus, only for women is that statistically significant at the 90 percent confidence interval. However, this rough measure of discrimination does not take into account the ways that human capital might be valued differently for Latvian's and non-Russians. The section on discrimination below explores these differences with greater analytic sophistication.

\section{Labor Supply Elasticities Across Groups}

As noted above, this analysis estimates labor supply elasticity by considering the effect of predicted earnings for all respondents on the probability that a person participates in the labor force. Table 4 presents estimates of those elasticities. The positive, statistically significant coefficient on predicted earnings suggests that as predicted earnings increase 1 percent, the probability that a non-Russian will supply labor increases by 1.24 percent. However, the negative significant coefficient $(-0.086)$ on the interaction term between predicted earnings and those of russian nationality offers evidence that Russians have lower labor supply elasticity than nonRussians. While a similar relationship holds in 1996, the coefficient on Russian labor supply elasticity is statistically significant only given a 88 percent confidence interval. That Russians 
have lower labor supply elasticity supports the use of a monopsony model to describe wages more below their marginal product than that of Latvians.

\section{Oaxaca Decomposition}

Like Table 3, Table 5 presents ordinary least squares regressions on log earnings. However, rather than stratifying by gender, it stratifies by ethnicity, providing information about the different earnings structures of Russians and Latvians by individual characteristics. These coefficients on earnings measure productivity and help decompose gross earnings differentials into explained productivity differences and differences attributable to ethnicity alone.

Latvians and Russians receive different returns for their human capital characteristics. Most notably, returns to education are much higher for Latvians. Compared to those with only primary education, Latvians with higher education receive 59 percent higher earnings: for Russians, the return is only 29 percent. While general secondary education offers a 17 percent return to Latvians, to Russians it offers no statistically significant earnings return. The age earnings profile for Latvians is less steep and less concave than that for Russians, suggesting that earnings for Russians away from the prime earnings years drops off much more steeply than for Latvians.

Using these stratified earnings regressions, we analyze earnings discrimination between Latvian and Russian using a Oaxaca decomposition. On average ${ }^{7}$ working Russians get paid 2.4 percent more than Latvians, so there does not seem to be earnings discrimination against this group. However, given their observable human capital characteristics of age and education, if Russians were paid in the same way as Latvians they would receive 7.9 percent more than Latvians. As a result, Russians are paid 5.5 percent less than they should be if only their human 
capital characteristics were considered according to the earnings structure of Latvians. If the

Russian earnings structure is used as the standard for appropriate payments to human capital, then

Russians would be paid 9.7 percent more than Latvians and the degree of discriminination against them would be 7.3 percent. ${ }^{8}$

Another way to consider this same information is to identify average earnings for men if they were paid as women and the average earnings of Russians if they were paid as Latvians.

Figure 1 presents this information. If Latvian's were paid according to a standard established for Russians, they would receive 68 Lats per month, while they actually get paid 73 Lats. Russians, who are actually paid 74 Lats per month, would receive 79 Lats per month if they were paid in the same way that Latvians are paid.

\section{Unemployment Bias}

Beyond this evidence for earnings discrimination, the analysis considers whether or not ethnicity biases unemployment. Cross-tabulations in Table 6 overview unemployment rates for the ILO definition using the LFS 98 data, that based on those who registered as unemployed using the LFS 98 data, and the ILO definition using the 1996 data. There is a large difference between unemployment rates when measured with the ILO standard (14.5 percent) and when measured by unemployment registration ( 6.9 percent $)^{9}$. According to these definitions, there was also a large drop in the ILO standard unemployment rate between 1996 and 1998: in 1996 the overall unemployment rate was 22.3 percent.

\footnotetext{
${ }^{7}$ Again, these figures are based on the geometric mean.

${ }^{8}$ The "human capital characteristics" on which this analysis is based does not include language ability, for that information was not in the data. Analysts in Latvia suggested that were differences in language included in the analysis, discrimination against Russians would be diminished, because Russians' inability to speak Latvian hinders their economic productivity.
} 
According to both definitions, Russians have a higher unemployment rate: 21.0 percent versus 10.8 percent for the ILO standard and 8.5 percent versus 6.0 percent for the registrationbased definition. However, the Russian unemployment rate is proportionately larger when the ILO standard definition is used. As discussed in the Appendix, if many Russians have ambiguous citizenship status or previously worked in firms that did not pay social tax, we would expect the registration-based definition to understate their unemployment.

The descriptive statistics above indicate the risk factors for unemployment, for unemployment rates are higher among Russians, among the young (see Figure 2 for an age breakdown of unemployment rates), and among people living in certain regions (particularly Latgale). However, they do not allow us to decompose carefully the individual characteristics that lead one to be more likely to be unemployed. For example, the Latgale unemployment rate could be particularly high because that region contains a high percentage of Russians, or potentially more young people. To distinguish between these separate effects of individual characteristics, we again use probit analysis. This allows us to determine the marginal effects of different characteristics on the probability that one will be unemployed, controlling for all the other characteristics present for an individual. As such it isolates aspects that unemployment policies should focus on.

Table 7 presents probit analyses of the risk factors for unemployment. To allow comparison between the ILO standard definition and a definition based on who registered as unemployed, it includes similar probits for both definitions. To consider whether the risk factors for unemployment have changed across time, it also includes analysis based on the LFS 96 data.

\footnotetext{
${ }^{9}$ The institutional appendix includes information about who is able to register for unemployment benefits, presenting the categories of who could be unemployed and still not be able to be included in the official unemployment statistics.
} 
Table 7 includes separate probit analyses for men and women. As Section III noted, to ease comparison of marginal probabilities, all the marginal effects across different samples in Table 7 are evaluated at the same probability. The standard comparison probability for all columns is that for men in the LFS 98 of 13.5 percent.

Controlling for education and region, those of non-Latvian nationality are significantly more likely to be unemployed. On average, being Russian entails a 7 percentage-point increase in the risk of being unemployed for men and a 10 percentage-point increase for women. Those nonLatvian men of nationality other than Russian are 4 percentage-points more likely to be unemployed and non-Latvian women are 6 points more likely.

After correcting for human capital, nationality and labor demand, differences in regional unemployment rates are not particularly large. Men living in urban areas are 12 percent more likely to be unemployed than those in rural areas, while women are 9 percent more likely. Beyond this overall urban increase, the city of Riga has a statistically different unemployment rate: men living in Riga are 5 percentage-points more likely to be unemployed, while women face an 8 percentage-point higher unemployment risk living there. Latgale also has an unemployment rate significantly different than Kurzeme, where unemployment rates are 9 percentage-points higher for men and 5 points higher for women

It is particularly interesting that nationality does not have as large an effect on registration as it does on unemployment. Russian and other non-Latvian men are no less likely to register for unemployment benefits than Latvian men, even though, as seen from the left column, they are more likely to be unemployed. Russian women and women of other nationalities are more likely than Latvians to register after controlling for human capital, marital status, and region, though the marginal effects of nationality on registration are less than on unemployment. Using those who 
register for benefits as a measure of unemployment underestimates the true effect of nationality, particularly for men.

As mentioned above, the ILO standard unemployment rate measured in 1996 was much higher than in 1998, e.g., 23 versus 16 percent for men and 22 versus 13 percent for women. Summarized in the right-most columns of Table 7, different risk factors for unemployment generate this overall change in level. As in 1998, non-Latvian's unemployment rates were significantly larger than Latvians, though the degree that ethnicity influences unemployment is not very different between 1996 and 1998.

\section{Selection into Registration}

Tables 6 and 7 call attention to important differences between the official ILO definition of unemployment and the Government of the Republic of Latvia's definition of the registered unemployed. Comparing the first two sets of columns of Table 7, we gain some insight into the factors that lead to being registered from those who are unemployed. Table 8 presents direct information about the characteristics of those from the pool of unemployed people who choose or are able to register with the State Employment Service. This gives us direct insight into how the definition of unemployment based on registration biases the picture of true unemployment.

Nationality has an interesting effect on ones ability to register for unemployment benefits.

In 1998, Russians were 9 percentage-points less likely to register for benefits than Latvians. However, in 1996 they were 6 percentage-points more likely to register. This change suggests that the potential to register for non-Latvians in general and Russians in particular lowered dramatically during this time period. While there appear to be few increases in Russians' unemployment probabilities, their likelihood of registering for unemployment benefits appears to be falling rapidly across time. 


\section{CONCLUSIONS}

Conventional wisdom suggests that ethnic tensions existing during central planning but were suppressed. Economic liberalization has allowed those tastes for discrimination to be expressed. However, the lack of perfect competition existing during post-communist transition provides an environment that supports discriminatory outcomes. Revisiting a monopsony approach to discrimination, this paper has explored the relationship between the lack of labor mobility in Latvia and the observed outcomes of ethnic wage differentials and labor market biases.

While there has been extended discussion over whether a monopsony model is an appropriate approach to discrimination in industrialized countries, there are several reasons that such a model would be particularly appropriate to post-Communist economies. During Communism, given the lack of geographic mobility and the presence of large employers with market power in discrete areas, labor markets were likely monopsonistic. As these economies move away from central-planning, monopsony likely persists. Investment in these economies is unevenly distributed, and there are several impediments to labor mobility. As a result, discrimination during transition can be partially attributed to monopsony, while it also likely results from prejudicial tastes that have only recently been expressed through market liberalization.

Examining discrimination against the Russian minority in Latvia, this paper offers evidence for the appropriateness of the monopsony approach. It is difficult to justify such an approach in industrialized countries because of market integration and problematic evidence concerning labor supply elasticities: according to the evidence presented, these difficulties do not arise in Latvia. Using employment concentration as a direct indicator, the paper offers evidence of monopsony in many local labor markets. Regional dummies in earnings equations show significant regional 
earnings disparities. These suggest labor markets in this geographically small economy are not particularly well integrated, providing further indirect evidence of monopsony. As estimated by the earnings effect on participation, Russians have labor supply elasticities significantly lower than Latvians. In the context of monopsony, this would suggest that Russians be paid earnings further below their marginal product than Latvians.

Earnings decompositions confirm earnings discrimination against the Russian minority. Although on average Russians are paid 2.4 percent more than Latvians, correcting for their human capital characteristics they should be paid 7.9 percent more, suggesting discrimination of approximately 5.5 percent when the Latvian earnings structure is used as the standard of labor market productivity. With the Russian structure as standard, discrimination is 7.3 percent.

Beyond that represented by wages, the paper provides evidence of biases in Russians' treatment with regard to unemployment and registration for unemployment benefits. With most of the transition unemployment literature, in Latvia most officially published unemployment data is based on who registers for benefits. According to this definition, there is little significant difference between Russians and Latvians after correcting for human capital characteristics. However, if one analyzes unemployment based on the ILO definition, there are significant differences in the probability of who is unemployed. Employing a new standardization technique to isolate the marginal effects of a particular variable across different groups, the paper illustrates that the probability of becoming unemployed is much higher for Russians using the ILO definition.

Among the pool of unemployed, those who are selected to register for unemployment benefits are much less likely to be Russian, ceteris paribus. This may offer some evidence of bias in the regulations concerning benefit registration. Despite the lower probability of registering for unemployment benefits, the paper offers some evidence of longer unemployment spells among 
Russians. This reinforces the findings of the literature concerning unemployment duration during transition: benefits packages have little effect on duration.

While offering support for a monopsony model to consider discrimination during transtion, the paper suggests several avenues for future research. With increased information about the dispersion of firms across Latvia, it would be useful to generate a more region-specific monopsony measure. Further, it would be worthwhile to extend this inquiry to other transition economies for comparison. Using this geographic variation, it would be interesting to analyse whether earnings discrimination varies by the degree of monopsony, as we would expect.

Further, with improved labor supply measures, it might be worthwhile to directly link elasticity to wage differentials. These innovations will be incorporated into future research, establishing more thoroughly how much a monopsony approach describes discrimination against ethnic minorities during post-Communist transition. 


\section{Institutional Appendix}

\section{Latvia's Unemployment Registration}

According to the Law on Employment, in Latvia those who are granted official unemployment status must:

- Be citizens of the Republic of Latvia or residents who have a permanent residence permit and a stamp of the population register in their passports;

- Be of working age;

- Be able to work;

- Not receive any salary or incomes of any kind of at least the size of the minimum wage;

- Not undertake any business activities;

- Be looking for a job;

- Be registered with the state employment service associated with his or her place of permanent residence; and

- At least once a month, visit the state employment service.

While many of its elements overlap with the ILO standard, under this definition, a person must register with the state employment service to gain unemployment status. These unemployment offices register those who ${ }^{10}$ :

- Have a stamp in their passports certifying that they live in the same jurisdiction as the employment office;

- Have received a labor registration document from their last employer certifying they no longer have a job; and

- Worked for an employer who paid social tax for nine of the previous 12 months.

As a result of these regulations, in Latvia one can identify several groups who cannot register as unemployed, even though they meet the ILO standard unemployment definition. For example, this definition of registration would exclude:

- Those with disputed Latvian citizenship, a situation arising given ambiguity about the rights of ethnic Russians or non-Latvian speakers;

- Those who have moved to a region of Latvia other than where their passports say they live, such as those who leave their homes in search of work;

- Those whose last employer faced financial difficulties before laying workers off, for those employers might be unable to pay social tax regularly in the 12 months prior to laying off workers;

- Those whose last job was as a self-employed worker or in a small entrepreneurial firm that would not issue labor registration documents;

\footnotetext{
${ }^{10}$ Across countries, it is reasonably standard to stipulate conditions like these to register for unemployment benefits. For example, in the United States the regulations concerning eligibility for unemployment insurance are variable and complex. Each state has its own eligibility requirements that are generally based on arcane bodies of legislation. It is generally beyond an individual citizen to ascertain whether or not she is eligible for benefits. Rather questions about eligibility are refered to administrative specialists.
} 
- Those choosing not to visit the state employment service once a month, perhaps because its benefits or services are unattractive; or

- Those unaware of the requirements necessary to register as unemployed.

These stipulations for registration create the potential for biased coverage in unemployment benefits. 


\section{References}

Ackland, Robert (1999), "Poverty in the Republic of Latvia in 1997/1998", Mimeo, World Bank, May 1999.

Arrow, Kenneth (1972), "Models of job discrimination”, in: A. H. Pascal, ed., Racial discrimination in economic life. Lexington, Ma: Lexington Books.

Brainard, Elizabeth (1998), "Winners and Losers in Russia's Economic Transition," American Economic Review, Vol. 88, No. 5.

Becker, Gary S. (1971), The Economics of Discrimination, $2^{\text {nd }}$ Edition, Chicago: University of Chicago Press.

Bell, Janice and Tomasz Mickeiwicz (1997), "Unemployment and State Sector Insiders During the Economic Transition in Poland”, MOCT-MOST 7: 131-157, Kluwer Academic Publishers.

Bergson, Abram (1944), The Structure of Soviet Wages. Cambridge, Mass.: Harvard University Press.

Cain, Glen G. (1986), "The Economic Analysis of Labor Market Discrimination: A Survey," Handbook of Labor Economics, Volume 1, O. Ashenfelter and R. Layard, eds., Elsevier.

Central Statistical Bureau of Latvia (1998), "Women and the Transition in Latvia”, mimeo, Riga.

Chase, Robert S. (1998), "Markets for Communist Human Capital: Returns to Education and Experience in the Czech Republic and Slovakia," Industrial and Labor Relations Review, Vol. 51, No. 3, April.

Cornelius, Peter K. (1995), "Unemployment during Transition: The Experience in the Baltic Countries", Communist Economics and Economic Transformation Vol. 7, No. 4.

Cotton, J. (1988), "On the Decomposition of Wage Differentials", The Review of Economics and Statistics, Vol. 70.

Fairris, David and Lori Kletzer (1991), "Working Conditions, Segmented Labor Markets, and Gender Discrimination" in: Cornwall, Richard and Phanindra Wunnava, eds. New Approaches to Economic and Social Analyses of Discrimination, Westport, Conn. and London: Greenwood, Praeger.

Fishback, Price (1998), “Operations of 'Unfettered' Labor Markets: Exit and Voice in American Labor Markets at the Turn of the Century", Journal of Economic Literature, Vol. 36, No. 2, June. 
Gassman, F. (1998), "Who and Where are the poor in Latvia", Mimeo, UNDP, June.

Gitter, Robert J. and Markus Scheuer (1998), "Low Unemployment in the Czech Republic: 'Miracle' or 'Mirage'," Monthly Labor Review, August.

Government of the Republic of Latvia (1997), Social Report 1996-1997.

Gora, Marek and Christoph M. Schmidt (1997), "Long-Term Unemployment, Unemployment Benefits and Social Assistance: The Polish Experience," Davidson Institute Working Paper 110, Ann Arbor, Michigan.

Gottfries, Nils and Barry McCormick (1995), "Discrimination and Open Unemployment in a Segmented Labour Market”, European Economic Review, Vol. 39, No. 1.

Haisken-DeNew, John P. and Christoph M. Schmidt (1997), "Interindustry and Interregion Differentials: Mechanics and Interpretations", Review of Economics and Statistics, Vo. 79, No. 3, August.

Ham, John C, Jan Svejnar and Katherine Terrell (1998), "Unemployment and the Social Safety Net During Transitions to a Market Economy: Evidence from the Czech and Slovak Republics," American Economic Review, Volume 88, Number 5, December.

Institute of Economics, Latvian Academy of Sciences (1998), “Activities in 1997/1998”, mimeo, Riga.

IMF Background Papers for Staff Report (1998), "Labor Market Issues in Latvia” (March 13).

Keune, Maarten (1998), "Poverty and The Labour Market in Latvia: Evidence from the Household Budget Survey and Labour Force Survey”, Mimeo, October.

Kolpin, Van and Larry Singell, Jr. (1997), "Asymmetric Information, Strategic Behavior, and Discrimination in the Labor Market", Economic Theory, Vol. 10. No. 1, June.

Kroncke, Charles and Kenneth Smith (1999), "The Wage Effects of Ethnicity in Estonia”, The Economics of Transition, EBRD, London.

Loza, Zana, Karlis Caunitis, and George-Stephan Barfub (1997), "Labor Market in Latvia 1996: Deployment and Analysis," Mimeo, Stockholm School of Economics.

Madden, Janice F. (1973) The Economics of Sex Discrimination. Lexington, Mass: D.C. Heath and Co.

Mickiewicz, Tomasz (1998), "Dismantling the State Sector in Eastern Europe: Implications for Unemployment", Communist Economics and Economic Transformation, Vol. 10(1), March. 
Mincer, Jacob (1974), Schooling, Experience and Earnings, National Bureau of Economic Research. New York: Columbia University Press.

Ministry of Economy, Republic of Latvia (1998); Economic Development of Latvia; Riga, December.

Naylor, Robin (1996), "Discrimination as Collusion in Imperfectly Competitive Labour Markets", Labour, Vol. 10, No. 2.

Oaxaca, Ronald L. (1973), "Male-Female Wage Differentials in Urban Labour Markets", International Economic Review, Vol. 14, No. 3, October.

Oaxaca, Ronald L. and Michael R. Ransom (1994), "On Discrimination and the Decomposition of Wage Differentials," Journal of Econometrics; 61(1), March.

Ransom, Michael R. (1993) "Seniority and Monopsony in the Academic Labor Market", American Economic Review, Vol. 83, No. 1, March.

Robinson, Joan (1934) The Economics of Imperfect Competition. London: Macmillan.

Rutkowski, Jan (1997), “Low Wage Employment in Transitional Economies of Central and Eastern Europe”, MOCT-MOST 7: 105-130, Kluwer Academic Publishers.

Sharir, Shmuel (1995), "Is Discriminatory Monopsony by Sex a Viable Model?", Journal of Economics (MVEA), Vol. 21, No. 2. 
Figure 1

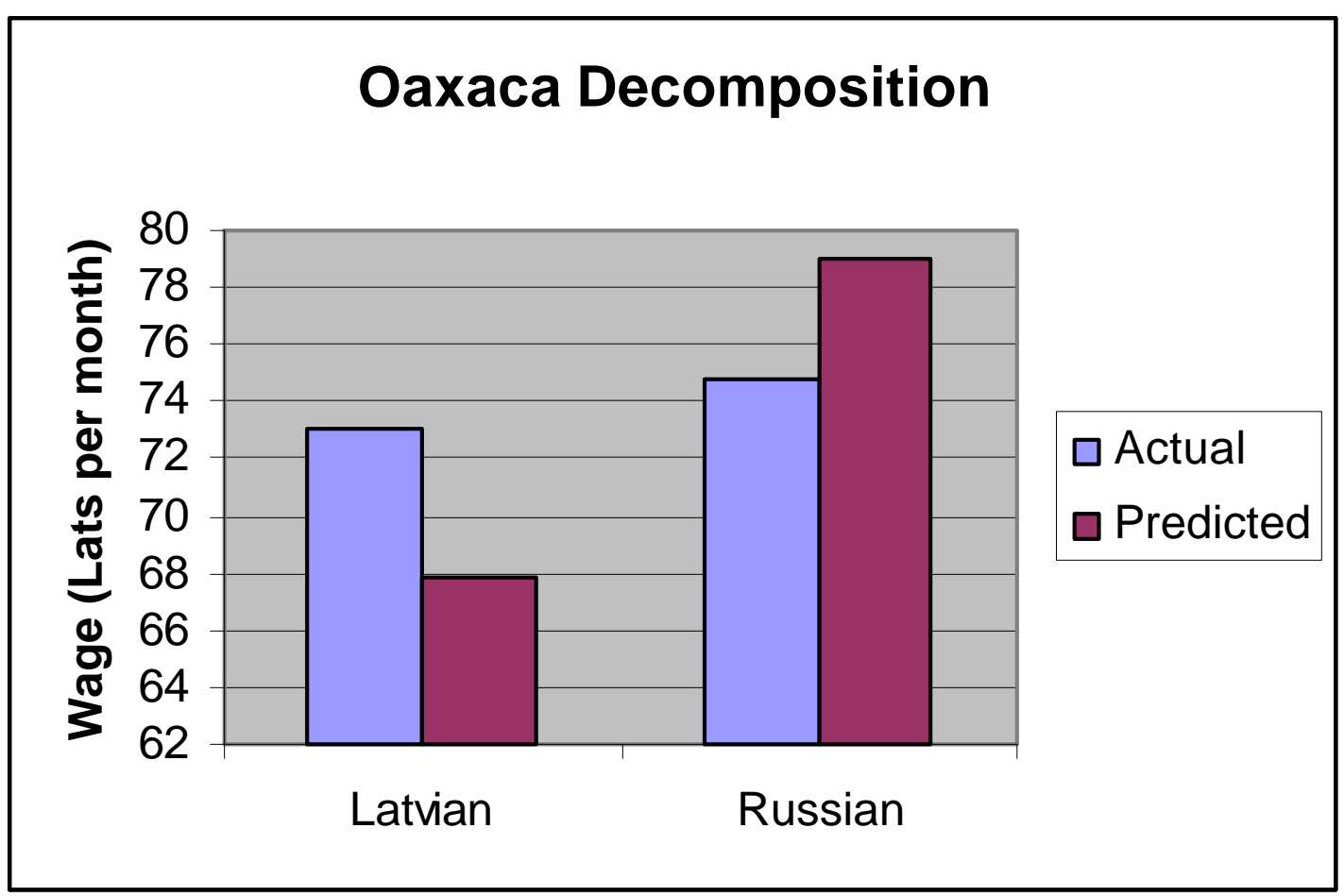


Figure 2

\section{Unemployment Rates by Age}

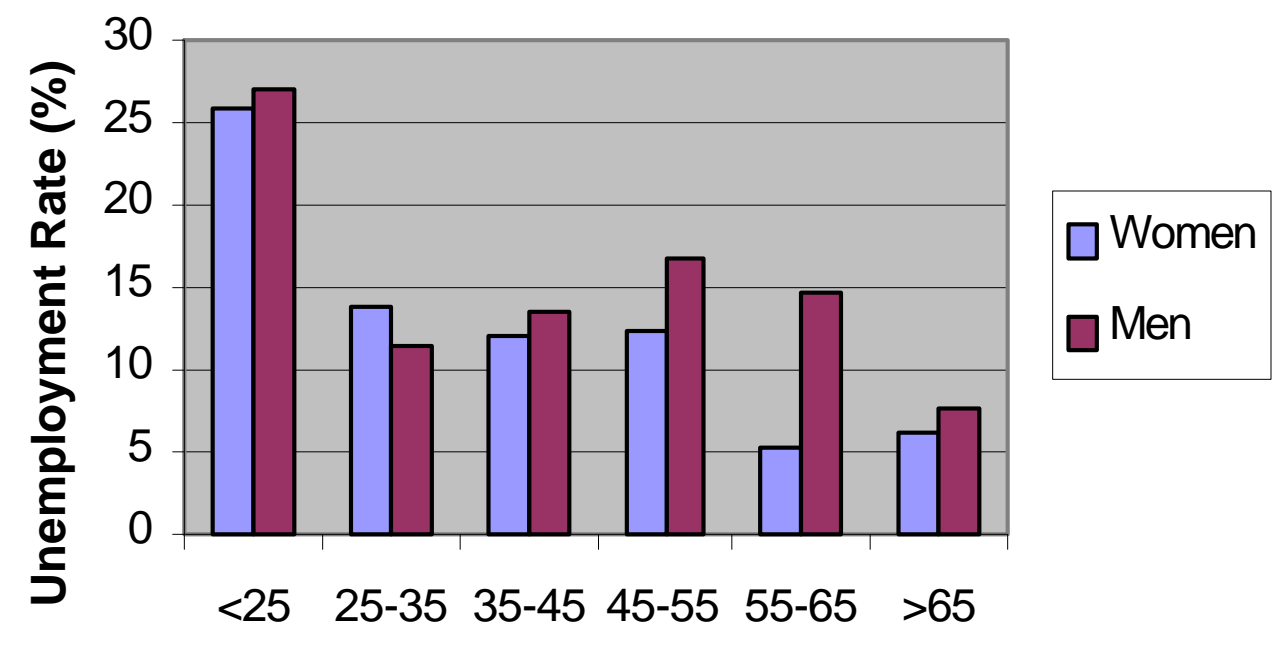

Age 
Table 1

Descriptive Statistics

\begin{tabular}{|c|c|c|c|c|c|c|}
\hline & \multicolumn{2}{|c|}{$\begin{array}{l}\text { Household Budget } \\
\text { Survey 1997:Q1 }\end{array}$} & \multicolumn{2}{|c|}{$\begin{array}{l}\text { Labor Force } \\
\text { Survey 1998:Q1 }\end{array}$} & \multicolumn{2}{|c|}{$\begin{array}{l}\text { Labor Force } \\
\text { Survey 1996:Q2 }\end{array}$} \\
\hline & Women & Men & Women & Men & Women & Men \\
\hline Earnings: main job (lats/mo.) & 74.47 & 95.47 &.$-^{-}$ &.$-^{-}$ &.-- &.$-^{-}$ \\
\hline [Log Variance] & {$[0.345]$} & {$[0.387]$} & & & & \\
\hline \multicolumn{7}{|l|}{ HUMAN CAPITAL } \\
\hline Higher Education & $24.8 \%$ & $19.5 \%$ & $-{ }^{-}$ &.-- & $-\cdot-$ &.$-^{-}$ \\
\hline Secondary Education & $66.5 \%$ & $61.8 \%$ & $-\cdot-$ &.-- &.-- & $-\cdot-$ \\
\hline Vocational Education & $2.4 \%$ & $7.5 \%$ & $-{ }^{-}$ & $-\because$ & $\because-$ & $-{ }^{-}$ \\
\hline Primary Education & $6.2 \%$ & $10.4 \%$ & $-\cdot-$ &.-- &.-- &.-- \\
\hline Less than Primary & $0.2 \%$ & $0.8 \%$ & $\because-$ & $-{ }^{-}$ & $-\because$ &.$-^{-}$ \\
\hline Higher Education &.-- & $-\cdot$ & $12.2 \%$ & $10.1 \%$ & $13.0 \%$ & $10.8 \%$ \\
\hline Secondary Specialized & $-\cdot$ & $-{ }^{-}$ & $19.7 \%$ & $18.0 \%$ & $22.6 \%$ & $19.7 \%$ \\
\hline Technical Secondary &.-- &.-- & $7.0 \%$ & $12.2 \%$ & $6.8 \%$ & $13.3 \%$ \\
\hline Comprehensive Secondary &.-- &.-- & $23.6 \%$ & $19.5 \%$ & $22.0 \%$ & $18.7 \%$ \\
\hline Vocational Education & $-\cdot$ & -- & $1.9 \%$ & $5.9 \%$ & $1.8 \%$ & $5.3 \%$ \\
\hline Basic Education & $-\cdot-$ & $-\cdot$ & $22.6 \%$ & $25.0 \%$ & $21.7 \%$ & $23.3 \%$ \\
\hline Less than Basic & $-\cdot$ & $-{ }^{-}$ & $11.9 \%$ & $8.9 \%$ & $10.9 \%$ & $8.3 \%$ \\
\hline No Formal Education &.-- &.-- & $1.0 \%$ & $0.4 \%$ & $1.2 \%$ & $0.6 \%$ \\
\hline Age & 40.2 & 40.0 & 47.7 & 43.6 & 46.1 & 42.1 \\
\hline (Standard Deviation) & $(11.3)$ & $(12.8)$ & $(19.5)$ & $(17.9)$ & $(18.5)$ & $(17.1)$ \\
\hline \multicolumn{7}{|l|}{ NATIONALITY } \\
\hline Latvian & $59.3 \%$ & $59.4 \%$ & $61.9 \%$ & $62.9 \%$ & $58.8 \%$ & $59.7 \%$ \\
\hline Russian & $30.3 \%$ & $30.7 \%$ & $27.0 \%$ & $26.0 \%$ & $29.1 \%$ & $28.3 \%$ \\
\hline Other Nationalities & $10.3 \%$ & $9.8 \%$ & $11.2 \%$ & $11.1 \%$ & $12.1 \%$ & $12.1 \%$ \\
\hline \multicolumn{7}{|l|}{ MARITAL STATUS } \\
\hline Married & $65.9 \%$ & $80.1 \%$ & $52.3 \%$ & $63.7 \%$ & $56.0 \%$ & $65.4 \%$ \\
\hline Single & $14.4 \%$ & $16.0 \%$ & $20.5 \%$ & $26.7 \%$ & $18.5 \%$ & $25.8 \%$ \\
\hline Divorced & $13.3 \%$ & $3.2 \%$ & $9.2 \%$ & $5.4 \%$ & $9.2 \%$ & $5.6 \%$ \\
\hline Widowed & $6.4 \%$ & $0.8 \%$ & $17.9 \%$ & $4.2 \%$ & $16.2 \%$ & $3.2 \%$ \\
\hline \multicolumn{7}{|l|}{ REGION } \\
\hline Riga City & $35.4 \%$ & $37.5 \%$ & $23.6 \%$ & $22.5 \%$ & $29.1 \%$ & $27.4 \%$ \\
\hline Riga Region & $15.3 \%$ & $13.8 \%$ & $10.6 \%$ & $10.8 \%$ & $10.3 \%$ & $10.3 \%$ \\
\hline Kurzene & $12.2 \%$ & $15.1 \%$ & $16.4 \%$ & $16.7 \%$ & $14.0 \%$ & $14.5 \%$ \\
\hline Vidzeme & $10.3 \%$ & $11.2 \%$ & $16.6 \%$ & $16.6 \%$ & $16.6 \%$ & $17.7 \%$ \\
\hline Zemgale & $13.0 \%$ & $11.3 \%$ & $14.5 \%$ & $13.8 \%$ & $13.7 \%$ & $13.5 \%$ \\
\hline Latgale & $13.8 \%$ & $11.2 \%$ & $18.4 \%$ & $19.7 \%$ & $16.3 \%$ & $16.5 \%$ \\
\hline Urban & $78.4 \%$ & $75.6 \%$ & $60.3 \%$ & $57.7 \%$ & $61.2 \%$ & $59.1 \%$ \\
\hline Number of Observations & 933 & 914 & 8304 & 6844 & 6221 & 5265 \\
\hline
\end{tabular}




\section{Table 2}

\section{Employment Concentration}

Percentage of Non-Farm Workers by District

Employed by Specific Industries

\begin{tabular}{|l|c|c|c|c|}
\hline \multicolumn{1}{|c|}{ Indicator } & Mean & Std. Dev. & Min. & Max. \\
\hline Top Three Industries & $48.0 \%$ & 6.78 & $31.3 \%$ & $60.3 \%$ \\
Top Two Industries & $36.0 \%$ & 6.13 & $22.1 \%$ & $49.0 \%$ \\
Top Industry & $21.5 \%$ & 5.15 & $11.8 \%$ & $32.7 \%$ \\
\hline N(Districts) & 32 & & & \\
\hline
\end{tabular}

Note: "Specific Industry" defined by 2-digit SIC codes. 
Table 3

Determinants of (Log) Earnings: Men vs. Women

Ordinary Least Squares Regressions (Absolute Values for T-Statistics in Parentheses)

\begin{tabular}{|c|c|c|}
\hline & Men & Women \\
\hline \multicolumn{3}{|l|}{ HUMAN CAPITAL (vs. Primary) } \\
\hline \multirow[t]{2}{*}{ Higher Education } & $0.54^{\star *}$ & $0.46^{* *}$ \\
\hline & $(7.62)$ & $(5.68)$ \\
\hline \multirow[t]{2}{*}{ Secondary Education } & $0.23^{* *}$ & 0.028 \\
\hline & (3.69) & $(0.38)$ \\
\hline \multirow[t]{2}{*}{ Vocational Education } & 0.11 & 0.15 \\
\hline & $(1.32)$ & $(1.10)$ \\
\hline \multirow[t]{2}{*}{ Age } & $0.023^{* *}$ & $0.040^{* *}$ \\
\hline & $(2.25)$ & $(3.42)$ \\
\hline \multirow[t]{2}{*}{ Age Squared (x 100) } & $-0.033^{* *}$ & $-0.052^{* *}$ \\
\hline & $(2.83)$ & (3.76) \\
\hline \multicolumn{3}{|l|}{ NATIONALITY (vs. Latvian) } \\
\hline \multirow[t]{2}{*}{ Russian } & -0.066 & $-0.069^{*}$ \\
\hline & $(1.53)$ & $(1.64)$ \\
\hline \multirow[t]{2}{*}{ Other Nationality } & -0.030 & -0.094 \\
\hline & $(0.47)$ & $(1.52)$ \\
\hline \multicolumn{3}{|l|}{ MARITAL STATUS (vs. Married) } \\
\hline \multirow[t]{2}{*}{ Single } & $-0.29^{* *}$ & -0.071 \\
\hline & $(4.48)$ & $(1.14)$ \\
\hline \multirow[t]{2}{*}{ Divorced } & $-0.17^{*}$ & -0.009 \\
\hline & $(1.64)$ & $(0.17)$ \\
\hline \multirow[t]{2}{*}{ Widowed } & -0.15 & 0.12 \\
\hline & $(0.71)$ & $(1.53)$ \\
\hline \multicolumn{3}{|l|}{ REGION (vs. Kurzeme) } \\
\hline \multirow[t]{2}{*}{ Riga City } & $0.14^{* *}$ & -0.045 \\
\hline & $(2.37)$ & $(0.73)$ \\
\hline \multirow[t]{2}{*}{ Riga Region } & 0.065 & -0.021 \\
\hline & $(0.95)$ & $(0.30)$ \\
\hline \multirow[t]{2}{*}{ Vidzeme } & $-0.21^{* *}$ & $-0.15^{\star *}$ \\
\hline & $(2.91)$ & $(2.01)$ \\
\hline \multirow[t]{2}{*}{ Zemgale } & -0.03 & -0.077 \\
\hline & $(0.42)$ & $(1.08)$ \\
\hline \multirow[t]{2}{*}{ Latgale } & $-0.26^{\star *}$ & $-0.26^{\star *}$ \\
\hline & (3.53) & (3.71) \\
\hline \multirow[t]{2}{*}{ Urban } & $0.27^{\star *}$ & $0.15^{\star *}$ \\
\hline & $(5.52)$ & (3.01) \\
\hline \multirow[t]{2}{*}{ Constant } & $3.70^{\star *}$ & $3.34^{* *}$ \\
\hline & (16.70) & (13.25) \\
\hline $\mathbf{N}$ & 914 & 933 \\
\hline R-squared & 0.24 & 0.16 \\
\hline
\end{tabular}


Table 4

Determinants of the Probability of Participating in the Labor Force Probit Estimates

(Z-scores in Parentheses)

\begin{tabular}{|c|c|c|}
\hline & Participation 1998 & Participation 1996 \\
\hline Predicted Earnings (Log) & $\begin{array}{l}1.24^{* *} \\
(55.81)\end{array}$ & $\begin{array}{l}1.09^{* *} \\
(44.25)\end{array}$ \\
\hline Earnings * Russian & $\begin{array}{c}-0.086^{* *} \\
(2.60)\end{array}$ & $\begin{array}{l}-0.057 \\
(1.57)\end{array}$ \\
\hline Russian & $\begin{array}{l}0.34^{* *} \\
(2.90)\end{array}$ & $\begin{array}{l}0.25^{\star} \\
(1.84)\end{array}$ \\
\hline Male & $\begin{array}{c}-0.059^{\star *} \\
(6.10)\end{array}$ & $\begin{array}{l}-0.022 \\
(2.05)\end{array}$ \\
\hline REGION (vs. Kurzeme) & & \\
\hline Riga City & $\begin{array}{c}-0.059^{* *} \\
(3.66)\end{array}$ & $\begin{array}{c}-0.039^{* *} \\
(2.19)\end{array}$ \\
\hline Riga Region & $\begin{array}{l}-0.016 \\
(0.91)\end{array}$ & $\begin{array}{l}-0.023 \\
(1.10)\end{array}$ \\
\hline Vidzeme & $\begin{array}{l}0.21^{* *} \\
(13.97)\end{array}$ & $\begin{array}{c}0.19^{* *} \\
(11.28)\end{array}$ \\
\hline Zemgale & $\begin{array}{c}0.056^{* *} \\
(3.41)\end{array}$ & $\begin{array}{c}0.053^{* *} \\
(2.87)\end{array}$ \\
\hline Latgale & $\begin{array}{l}0.21^{* *} \\
(13.67)\end{array}$ & $\begin{array}{l}0.20^{* *} \\
(12.00)\end{array}$ \\
\hline Urban & $\begin{array}{l}-0.30^{\star *} \\
(26.74)\end{array}$ & $\begin{array}{l}-0.19^{* *} \\
(15.39)\end{array}$ \\
\hline Number of Observations & 15148 & 11486 \\
\hline Log-Likelihood & -7380.6 & -5750.0 \\
\hline Observed Probability & 0.576 & 0.619 \\
\hline Predicted Probability & 0.590 & 0.647 \\
\hline
\end{tabular}

*Statistically significant at the .10 level; ${ }^{* *}$ statistically significant at .05 level

Data Source: Labor Force Surveys 
Table 5

Determinants of (Log) Earnings: Latvians vs. Russians

Ordinary Least Squares Regressions (Absolute Values for T-Statistics in Parentheses)

\begin{tabular}{|c|c|c|}
\hline & Latvian & Russian \\
\hline \multicolumn{3}{|l|}{ HUMAN CAPITAL (vs. Primary) } \\
\hline \multirow[t]{2}{*}{ Higher Education } & $0.59^{* *}$ & $0.29^{* *}$ \\
\hline & (8.69) & (2.73) \\
\hline \multirow[t]{2}{*}{ Secondary Education } & $0.17^{\star *}$ & -0.023 \\
\hline & $(2.70)$ & $(0.24)$ \\
\hline \multirow[t]{2}{*}{ Vocational Education } & 0.029 & 0.052 \\
\hline & $(0.31)$ & $(0.38)$ \\
\hline \multirow[t]{2}{*}{ Age } & $0.027^{\star *}$ & $0.048^{* *}$ \\
\hline & $(2.77)$ & $(3.26)$ \\
\hline Age Squared (x 100) & $\begin{array}{c}-0.038^{* *} \\
(3.41)\end{array}$ & $\begin{array}{c}-0.062^{* *} \\
(3.48)\end{array}$ \\
\hline \multirow[t]{2}{*}{ MALE } & $0.27^{\star *}$ & $0.32^{* *}$ \\
\hline & $(7.56)$ & $(7.13)$ \\
\hline \multicolumn{3}{|l|}{ MARITAL STATUS (vs. Married) } \\
\hline \multirow[t]{2}{*}{ Single } & $-0.20^{* *}$ & $-0.17^{\star *}$ \\
\hline & $(3.50)$ & $(2.14)$ \\
\hline \multirow[t]{2}{*}{ Divorced } & -0.035 & -0.087 \\
\hline & $(0.52)$ & $(1.11)$ \\
\hline \multirow[t]{2}{*}{ Widowed } & 0.091 & -0.025 \\
\hline & $(0.90)$ & $(0.23)$ \\
\hline \multicolumn{3}{|l|}{ REGION (vs. Kurzeme) } \\
\hline \multirow[t]{2}{*}{ Riga City } & 0.069 & -0.053 \\
\hline & $(1.23)$ & $(0.70)$ \\
\hline \multirow[t]{2}{*}{ Riga Region } & 0.091 & -0.13 \\
\hline & $(1.47)$ & $(1.47)$ \\
\hline \multirow[t]{2}{*}{ Vidzeme } & $-0.16^{\star *}$ & $-0.39^{* *}$ \\
\hline & $(2.51)$ & $(2.55)$ \\
\hline \multirow[t]{2}{*}{ Zemgale } & 0.031 & $-0.33^{\star *}$ \\
\hline & $(0.49)$ & $(3.10)$ \\
\hline \multirow[t]{2}{*}{ Latgale } & $-0.22^{\star *}$ & $-0.37^{\star *}$ \\
\hline & $(3.10)$ & $(4.13)$ \\
\hline \multirow[t]{2}{*}{ Urban } & $0.20^{* *}$ & $0.23^{* *}$ \\
\hline & $(4.89)$ & (2.96) \\
\hline \multirow[t]{2}{*}{ Constant } & $3.41^{* *}$ & $3.22^{* \star}$ \\
\hline & (15.79) & (10.01) \\
\hline $\mathbf{N}$ & 1097 & 564 \\
\hline R-squared & 0.22 & 0.26 \\
\hline
\end{tabular}


Table 6

Unemployment Rates

By Gender, Unemployment Definition and Year

\begin{tabular}{|c|c|c|c|}
\hline & UE (ILO) 1998 & UE (Reg.) 1998 & UE (ILO) 1996 \\
\hline LATVIA & $14.5 \%$ & $6.9 \%$ & $22.6 \%$ \\
\hline Men & $15.6 \%$ & $6.2 \%$ & $23.0 \%$ \\
\hline Women & $13.3 \%$ & $7.6 \%$ & $22.1 \%$ \\
\hline \multicolumn{4}{|l|}{ NATIONALITY } \\
\hline Latvian & $10.8 \%$ & $6.0 \%$ & $17.4 \%$ \\
\hline Russian & $21.0 \%$ & $8.5 \%$ & $29.2 \%$ \\
\hline \multicolumn{4}{|c|}{ GEOGRAPHIC AREA } \\
\hline Urban & $17.5 \%$ & $7.6 \%$ & $25.1 \%$ \\
\hline Riga City & $17.6 \%$ & $5.3 \%$ & $25.0 \%$ \\
\hline Riga Region & $11.7 \%$ & $3.3 \%$ & $20.5 \%$ \\
\hline Kurzeme & $11.3 \%$ & $5.8 \%$ & $19.9 \%$ \\
\hline Vidzeme & $11.0 \%$ & $7.0 \%$ & $18.4 \%$ \\
\hline Zemgale & $12.3 \%$ & $6.6 \%$ & $21.7 \%$ \\
\hline Latgale & $18.5 \%$ & $16.0 \%$ & $26.1 \%$ \\
\hline \multicolumn{4}{|l|}{ AGE GROUP } \\
\hline$<25$ & $26.5 \%$ & $11.8 \%$ & $33.7 \%$ \\
\hline $25-35$ & $12.6 \%$ & $6.2 \%$ & $21.4 \%$ \\
\hline $35-45$ & $12.9 \%$ & $6.4 \%$ & $18.6 \%$ \\
\hline $45-55$ & $14.3 \%$ & $7.3 \%$ & $18.8 \%$ \\
\hline $55-65$ & $10.9 \%$ & $5.1 \%$ & $24.6 \%$ \\
\hline
\end{tabular}

Data Source: Labor Force Survey 
Table 7

Determinants of the Probability of Being Unemployed Probit Estimates by Gender, Unemployment Definition, and Year (Z-Scores in Parentheses)

\begin{tabular}{|c|c|c|c|c|c|c|}
\hline & \multicolumn{2}{|c|}{ UE (ILO) 1998} & \multicolumn{2}{|c|}{ UE (Registered) 1998} & \multicolumn{2}{|c|}{ UE (ILO) 1996} \\
\hline & Men & Women & Men & Women & Men & Women \\
\hline $\begin{array}{l}\text { HUMAN CAPITAL (vs. <Primary) } \\
\text { Higher Education }\end{array}$ & $\begin{array}{c}-0.14^{\star *} \\
(9.59)\end{array}$ & $\begin{array}{c}-0.11^{\star *} \\
(5.39)\end{array}$ & $\begin{array}{c}-0.15^{\star \star} \\
(6.45)\end{array}$ & $\begin{array}{c}-0.12^{\star \star} \\
(5.05)\end{array}$ & $\begin{array}{c}-0.13^{\star *} \\
(9.13)\end{array}$ & $\begin{array}{c}-0.13^{* *} \\
(8.33)\end{array}$ \\
\hline Secondary Specialized & $\begin{array}{l}-0.12^{\star *} \\
(8.36)\end{array}$ & $\begin{array}{c}-0.068^{\star *} \\
(3.20)\end{array}$ & $\begin{array}{c}-0.11^{* *} \\
(5.83)\end{array}$ & $\begin{array}{c}-0.068^{* *} \\
(2.81)\end{array}$ & $\begin{array}{c}-0.11^{\star *} \\
(8.06)\end{array}$ & $\begin{array}{c}-0.096^{* *} \\
(5.92)\end{array}$ \\
\hline Technical Secondary & $\begin{array}{c}-0.084^{\star *} \\
(5.80)\end{array}$ & $\begin{array}{l}-0.037 \\
(1.52)\end{array}$ & $\begin{array}{c}-0.067^{* *} \\
(3.17)\end{array}$ & $\begin{array}{c}-0.049^{\star} \\
(1.79)\end{array}$ & $\begin{array}{c}-0.080^{* *} \\
(5.48)\end{array}$ & $\begin{array}{c}-0.074^{\star *} \\
(3.67)\end{array}$ \\
\hline Comprehensive Secondary & $\begin{array}{c}-0.069^{\star *} \\
(4.87)\end{array}$ & $\begin{array}{l}0.000 \\
(0.02)\end{array}$ & $\begin{array}{c}-0.044^{\star *} \\
(2.18)\end{array}$ & $\begin{array}{l}-0.026 \\
(1.07)\end{array}$ & $\begin{array}{c}-0.057^{\star \star} \\
(3.78)\end{array}$ & $\begin{array}{c}-0.047^{* *} \\
(2.66)\end{array}$ \\
\hline Vocational Education & $\begin{array}{l}-0.060^{* *} \\
(3.00)\end{array}$ & $\begin{array}{l}-0.011 \\
(0.28)\end{array}$ & $\begin{array}{l}-0.041 \\
(1.51)\end{array}$ & $\begin{array}{l}-0.013 \\
(0.28)\end{array}$ & $\begin{array}{l}-0.009 \\
(0.39)\end{array}$ & $\begin{array}{l}0.001 \\
(0.03)\end{array}$ \\
\hline Age & $\begin{array}{c}-0.005^{\star} \\
(1.77)\end{array}$ & $\begin{array}{c}-0.009^{* *} \\
(3.18)\end{array}$ & $\begin{array}{l}-0.001 \\
(0.42)\end{array}$ & $\begin{array}{l}0.003 \\
(0.68)\end{array}$ & $\begin{array}{c}-0.012^{\star *} \\
(5.24)\end{array}$ & $\begin{array}{c}-0.016^{\star *} \\
(7.03)\end{array}$ \\
\hline $\begin{array}{l}\text { Age Squared (x100) } \\
\text { NATIONALITY (vs. Latvian) }\end{array}$ & $\begin{array}{l}0.004 \\
(1.30)\end{array}$ & $\begin{array}{l}0.006^{*} \\
(1.84)\end{array}$ & $\begin{array}{l}0.001 \\
(0.24)\end{array}$ & $\begin{array}{l}-0.007 \\
(1.52)\end{array}$ & $\begin{array}{c}0.012^{* *} \\
(4.49)\end{array}$ & $\begin{array}{c}0.019^{\star *} \\
(6.87)\end{array}$ \\
\hline Russian & $\begin{array}{c}0.066^{* *} \\
(5.27)\end{array}$ & $\begin{array}{l}0.10^{\star *} \\
(7.26)\end{array}$ & $\begin{array}{l}-0.011 \\
(0.74)\end{array}$ & $\begin{array}{c}0.077^{* *} \\
(4.64)\end{array}$ & $\begin{array}{c}0.072^{* *} \\
(5.65)\end{array}$ & $\begin{array}{c}0.097^{* *} \\
(6.80)\end{array}$ \\
\hline Other Nationality & $\begin{array}{l}0.039 * * \\
(2.19)\end{array}$ & $\begin{array}{l}0.058^{* *} \\
(2.86)\end{array}$ & $\begin{array}{l}0.012 \\
(0.53)\end{array}$ & $\begin{array}{l}0.043^{*} \\
(1.80)\end{array}$ & $\begin{array}{c}0.050^{\star *} \\
(2.83)\end{array}$ & $\begin{array}{l}0.11^{* *} \\
(5.50)\end{array}$ \\
\hline LABOR DEMAND & & & & & & \\
\hline Long-Term Job Growth & $\begin{array}{l}-0.16^{\star \star} \\
(2.34)\end{array}$ & $\begin{array}{l}-0.044 \\
(0.58)\end{array}$ & $\begin{array}{l}-0.10^{\star *} \\
(3.07)\end{array}$ & $\begin{array}{c}-0.12 \\
(1.39)\end{array}$ & $\begin{array}{l}0.026 \\
(0.32)\end{array}$ & $\begin{array}{l}0.017 \\
(0.20)\end{array}$ \\
\hline $\begin{array}{l}\text { Vacancy/Employment Ratio } \\
\text { REGION (vs. Rural \& Kurzeme) }\end{array}$ & $\begin{array}{l}-0.60 \\
(0.15)\end{array}$ & $\begin{array}{l}-6.690 \\
(1.45)\end{array}$ & $\begin{array}{c}-13.13^{* *} \\
(2.44)\end{array}$ & $\begin{array}{l}-3.96 \\
(1.41)\end{array}$ & $\begin{array}{l}8.48^{*} \\
(1.94)\end{array}$ & $\begin{array}{l}-6.31 \\
(1.21)\end{array}$ \\
\hline Riga City & $\begin{array}{l}0.048^{*} \\
(1.65)\end{array}$ & $\begin{array}{c}0.078^{* *} \\
(2.23)\end{array}$ & $\begin{array}{l}0.10^{* *} \\
(2.35)\end{array}$ & $\begin{array}{l}0.025 \\
(0.71)\end{array}$ & $\begin{array}{l}-0.011 \\
(0.50)\end{array}$ & $\begin{array}{l}0.024 \\
(0.92)\end{array}$ \\
\hline Riga Region & $\begin{array}{l}0.017 \\
(0.79)\end{array}$ & $\begin{array}{l}0.024 \\
(0.99)\end{array}$ & $\begin{array}{l}-0.022 \\
(0.71)\end{array}$ & $\begin{array}{l}-0.035 \\
(1.37)\end{array}$ & $\begin{array}{c}0.066^{* *} \\
(2.84)\end{array}$ & $\begin{array}{c}-0.048^{* *} \\
(2.48)\end{array}$ \\
\hline Vidzeme & $\begin{array}{l}0.014 \\
(0.60)\end{array}$ & $\begin{array}{c}0.058^{* *} \\
(2.17)\end{array}$ & $\begin{array}{l}0.052^{*} \\
(1.65)\end{array}$ & $\begin{array}{c}0.064^{* *} \\
(2.14)\end{array}$ & $\begin{array}{l}0.044^{*} \\
(1.96)\end{array}$ & $\begin{array}{c}-0.022 \\
(1.02)\end{array}$ \\
\hline Zemgale & $\begin{array}{l}0.019 \\
(0.80)\end{array}$ & $\begin{array}{l}0.014 \\
(0.54)\end{array}$ & $\begin{array}{l}0.065^{*} \\
(1.89)\end{array}$ & $\begin{array}{c}0.023 \\
0.78\end{array}$ & $\begin{array}{l}0.022 \\
(1.01)\end{array}$ & $\begin{array}{l}-0.028 \\
(1.43)\end{array}$ \\
\hline Latgale & $\begin{array}{c}0.091^{* *} \\
(3.76)\end{array}$ & $\begin{array}{c}0.052^{* *} \\
(2.01)\end{array}$ & $\begin{array}{l}0.23^{\star *} \\
(6.58)\end{array}$ & $\begin{array}{l}0.11^{* *} \\
(3.68)\end{array}$ & $\begin{array}{c}0.091^{* *} \\
(3.78)\end{array}$ & $\begin{array}{l}0.023 \\
(1.01)\end{array}$ \\
\hline Urban & $\begin{array}{l}0.12^{* *} \\
(8.95)\end{array}$ & $\begin{array}{l}0.088^{* *} \\
(6.42)\end{array}$ & $\begin{array}{l}0.094^{\star *} \\
(5.80)\end{array}$ & $\begin{array}{l}0.055^{\star *} \\
(4.03)\end{array}$ & $\begin{array}{l}0.050^{* *} \\
(4.90)\end{array}$ & $\begin{array}{c}0.062^{* *} \\
(5.00)\end{array}$ \\
\hline Number of Observations & 4507 & 4230 & 4148 & 4025 & 3727 & 3380 \\
\hline Log-Likelihood & -1792.8 & -1511.0 & -856.3 & -998.8 & -1869.2 & -1628.6 \\
\hline Observed Probability & 0.156 & 0.133 & 0.062 & 0.076 & 0.230 & 0.221 \\
\hline Comparison Probability1 & 0.135 & 0.135 & 0.135 & 0.135 & 0.135 & 0.135 \\
\hline
\end{tabular}

${ }^{*}$ Statistically significant at the .10 level; ${ }^{* *}$ statistically significant at .05 level

1 Marginal effects for all sub-samples are compared at the predicted probability for the male 1998 sub-sample.

Data Source: Labor Force Survey 
Table 8

Selection into Registered Unemployed

Probit Estimates by Year

(Z-scores in parentheses)

\begin{tabular}{|c|c|c|}
\hline & 1998 & 1996 \\
\hline MALE & $\begin{array}{l}-0.12^{\star \star} \\
(4.03)\end{array}$ & $\begin{array}{c}-0.069^{\star \star} \\
(2.97)\end{array}$ \\
\hline \multicolumn{3}{|l|}{ HUMAN CAPITAL (vs. <Primary) } \\
\hline Higher Education & $\begin{array}{l}-0.074 \\
(1.18)\end{array}$ & $\begin{array}{l}-0.041 \\
(0.89)\end{array}$ \\
\hline Secondary Specialized & $\begin{array}{l}0.018 \\
(0.36)\end{array}$ & $\begin{array}{l}-0.036 \\
(1.04)\end{array}$ \\
\hline Technical Secondary & $\begin{array}{l}-0.015 \\
(0.30)\end{array}$ & $\begin{array}{l}0.018 \\
(0.45)\end{array}$ \\
\hline Comprehensive Secondary & $\begin{array}{l}-0.005 \\
(0.11)\end{array}$ & $\begin{array}{l}-0.045 \\
(1.37)\end{array}$ \\
\hline Vocational Education & $\begin{array}{l}0.026 \\
(0.34)\end{array}$ & $\begin{array}{l}0.041 \\
(0.72)\end{array}$ \\
\hline Age & $\begin{array}{c}0.019^{* *} \\
(2.44)\end{array}$ & $\begin{array}{c}0.032^{* *} \\
(5.49)\end{array}$ \\
\hline Age Squared (x100) & $\begin{array}{c}-0.022^{* *} \\
(2.17)\end{array}$ & $\begin{array}{c}-0.043^{* *} \\
(5.84)\end{array}$ \\
\hline NATIONALITY (vs. Latvian) & & \\
\hline Russian & $\begin{array}{c}-0.093^{* *} \\
(2.88)\end{array}$ & $\begin{array}{c}0.057^{* *} \\
(2.14)\end{array}$ \\
\hline Other Nationality & $\begin{array}{l}-0.070 \\
(1.51)\end{array}$ & $\begin{array}{l}0.029 \\
(0.83)\end{array}$ \\
\hline REGION (vs. Rural \& Kurzem & & \\
\hline Riga City & $\begin{array}{l}-0.18^{* *} \\
(3.73)\end{array}$ & $\begin{array}{c}-0.16^{* *} \\
(4.29)\end{array}$ \\
\hline Riga Region & $\begin{array}{l}-0.21^{* *} \\
(3.78)\end{array}$ & $\begin{array}{c}-0.085^{\star *} \\
(2.01)\end{array}$ \\
\hline Vidzeme & $\begin{array}{l}-0.012 \\
(0.19)\end{array}$ & $\begin{array}{c}-0.096^{* *} \\
(2.24)\end{array}$ \\
\hline Zemgale & $\begin{array}{l}0.005 \\
(0.08)\end{array}$ & $\begin{array}{l}0.080^{*} \\
(1.73)\end{array}$ \\
\hline Latgale & $\begin{array}{l}0.23^{* *} \\
(3.99)\end{array}$ & $\begin{array}{c}0.091^{* *} \\
(2.03)\end{array}$ \\
\hline Urban & $\begin{array}{l}-0.054 \\
(1.21)\end{array}$ & $\begin{array}{l}-0.016 \\
(0.53)\end{array}$ \\
\hline Number of Observations & 1140 & 1516 \\
\hline Log-Likelihood & -658.5 & -788.0 \\
\hline Observed Probability & 0.353 & 0.264 \\
\hline Predicted Probability & 0.337 & 0.236 \\
\hline
\end{tabular}

Data Source: Labor Force Survey 


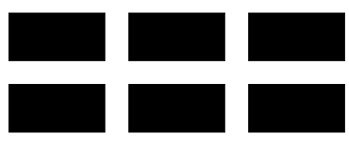

THE WILLIAM DAVIDSON INSTITUTE

AT THE UNIVERSITY OF MICHIGAN BUSINESSSCHOOL

\section{DAVIDSON INSTITUTE WORKING PAPER SERIES - Most Recent Papers}

The entire Working Paper Series is available at: www.wdi.bus.umich.edu

CURRENT AS OF $7 / 12 / 01$

\begin{tabular}{|c|c|c|}
\hline Publication & Authors & Date \\
\hline $\begin{array}{l}\text { No. } 381 \text { Labor Market Discrimination During Post-Communist } \\
\text { Transition: A Monopsony Approach to the Status of Latvia's Russian } \\
\text { Minority }\end{array}$ & Robert S. Chase & Sept. 2000 \\
\hline No. 380 Dollarization of Liabilities in Non-tradable Goods Sector & Frédéric Chabellard & June 2001 \\
\hline $\begin{array}{l}\text { No. } 379 \text { Lessons from the Russian Meltdown: The Economics of Soft } \\
\text { Legal Constraints }\end{array}$ & Enrico Perotti & Mar. 2001 \\
\hline No. 378 Effective Tax Rates in Transition & Vlad Ivanenko & May 2001 \\
\hline $\begin{array}{l}\text { No. } 377 \text { Some Explanations for Changes in the Distribution of } \\
\text { Household Income in Slovakia: } 1988 \text { and } 1996\end{array}$ & $\begin{array}{l}\text { Thesia Garner and Katherine } \\
\text { Terrell }\end{array}$ & May 2001 \\
\hline $\begin{array}{l}\text { No. } 376 \text { Competition and Enterprise Performance in Transition } \\
\text { Economies: Evidence from a Cross-country Survey }\end{array}$ & $\begin{array}{l}\text { Wendy Carlin, Steven Fries, } \\
\text { Mark Schaffer and Paul Seabright }\end{array}$ & May 2001 \\
\hline $\begin{array}{l}\text { No. } 375 \text { Why More is Actually Less: New Interpretations of China's } \\
\text { Labor-Intensive FDI }\end{array}$ & Yasheng Huang & May 2001 \\
\hline No. 374 Economic Fragmentation and FDI in China & Yasheng Huang & May 2001 \\
\hline $\begin{array}{l}\text { No. } 373 \text { Earnings Disparities in the Czech Republic: Evidence of the } \\
\text { Past Decade and Cross-National Comparison }\end{array}$ & Jiri Vecernik & May 2001 \\
\hline $\begin{array}{l}\text { No. } 372 \text { Economic Reform, Democracy and Growth During Post- } \\
\text { Communist Transition }\end{array}$ & Jan Fidrmuc & Mar. 2001 \\
\hline $\begin{array}{l}\text { No. } 371 \text { Do Multinational Enterprises Substitute Parent Jobs for Foreign } \\
\text { Ones? Evidence from Firm Level Panel Data }\end{array}$ & Jozef Konings and Alan Murphye & Apr. 2001 \\
\hline $\begin{array}{l}\text { No. } 370 \text { From Needs to the Market: Changing Inequality of Household } \\
\text { Income in the Czech Transition }\end{array}$ & Jiri Vecernik & Apr. 2001 \\
\hline $\begin{array}{l}\text { No. } 369 \text { Competition and Corporate Governance: Substitutes or } \\
\text { Complements? Evidence from the Warsaw Stock Exchange }\end{array}$ & $\begin{array}{l}\text { Irena Grosfeld and Thierry } \\
\text { Tressel }\end{array}$ & Mar. 2001 \\
\hline $\begin{array}{l}\text { No. } 368 \text { Multinational Corporations as Catalyst for Industrial } \\
\text { Development: The Case of Poland }\end{array}$ & $\begin{array}{l}\text { Carlo Altomonte and Laura } \\
\text { Resmini }\end{array}$ & Feb. 2001 \\
\hline No. 367 A Multi-Task Theory of the State Enterprise Reform & $\begin{array}{l}\text { Chong-En Bai, David D. Li, } \\
\text { Zhigang Tao, and Yijiang Wang }\end{array}$ & Mar. 2001 \\
\hline No. 366a Confidence Building in Emerging Stock Markets & Enrico C. Perotti and Luc Laeven & June 2001 \\
\hline No. 366 Confidence Building in Emerging Stock Markets & $\begin{array}{l}\text { Enrico C. Perotti, Luc Laeven, } \\
\text { and Pieter van Oijen }\end{array}$ & Dec. 2000 \\
\hline $\begin{array}{l}\text { No. } 365 \text { Incentive Contracting versus Ownership Reforms: Evidence } \\
\text { from China's Township and Village Enterprises }\end{array}$ & $\begin{array}{l}\text { Chun Chang, Brian McCall, and } \\
\text { Yijang Wang }\end{array}$ & Nov. 2000 \\
\hline $\begin{array}{l}\text { No. } 364 \text { Individual Pay and Outside Options: Evidence from the Polish } \\
\text { Labour Force Survey }\end{array}$ & $\begin{array}{l}\text { Fiona Duffy and Patrick Paul } \\
\text { Walsh }\end{array}$ & Mar. 2001 \\
\hline $\begin{array}{l}\text { No. } 363 \text { Investment, Credit Rationing and the Soft Budget Constraint: } \\
\text { Evidence from Czech Panel Data (revised Davidson Institute Working } \\
\text { Paper No. 60a) }\end{array}$ & Lubomír Lízal and Jan Svejnar & Feb. 2001 \\
\hline $\begin{array}{l}\text { No. } 362 \text { A Network Perspective on Inter-Organizational Transfer of } \\
\text { R\&D Capabilities: A Study of International Joint Ventures in Chinese } \\
\text { Automobile Industry }\end{array}$ & $\begin{array}{l}\text { Zheng Zhao, Jaideep Anand and } \\
\text { Will Mitchell }\end{array}$ & Feb. 2001 \\
\hline $\begin{array}{l}\text { No. } 361 \text { Network Restructuring and Firm Creation in East-Central } \\
\text { Europe: A Public-Private Venture }\end{array}$ & Gerald A. McDermott & Dec. 2000 \\
\hline $\begin{array}{l}\text { No. } 360 \text { Responses of Private and Public Schools to Voucher Funding: } \\
\text { The Czech and Hungarian Experience }\end{array}$ & $\begin{array}{l}\text { Randall K. Filer and Daniel } \\
\text { Münich }\end{array}$ & Oct. 2000 \\
\hline
\end{tabular}




\begin{tabular}{|c|c|c|}
\hline $\begin{array}{l}\text { No. } 359 \text { Labor Market Uncertainty and Private Sector Labor Supply in } \\
\text { Russia }\end{array}$ & Steven Stillman & Sept. 2000 \\
\hline $\begin{array}{l}\text { No. } 358 \text { Russian Roulette-Expenditure Inequality and Instability in } \\
\text { Russia, 1994-1998 }\end{array}$ & Branko Jovanovic & Sept. 2000 \\
\hline No. 357 Dealing with the Bad Loans of the Chinese Banks & John P. Bonin and Yiping Huang & Jan. 2001 \\
\hline No. 356 Retail Banking in Hungary: A Foreign Affair? & John P. Bonin and István Ábel & Dec. 2000 \\
\hline $\begin{array}{l}\text { No. } 355 \text { Optimal Speed of Transition: Micro Evidence from the Czech } \\
\text { Republic }\end{array}$ & $\begin{array}{l}\text { Stepan Jurajda and Katherine } \\
\text { Terrell }\end{array}$ & Dec. 2000 \\
\hline No. 354 Political Instability and Growth in Dictatorships & $\begin{array}{l}\text { Jody Overland, Kenneth L. } \\
\text { Simons and Michael Spagat }\end{array}$ & Nov. 2000 \\
\hline No. 353 Disintegration and Trade & Jarko Fidrmuc and Jan Fidrmuc & Nov. 2000 \\
\hline $\begin{array}{l}\text { No. } 352 \text { Social Capital and Entrepreneurial Performance in Russia: A } \\
\text { Panel Study }\end{array}$ & Bat Batjargal & Dec. 2000 \\
\hline $\begin{array}{l}\text { No. 351 Entrepreneurial Versatility, Resources and Firm Performance in } \\
\text { Russia: A Panel Study }\end{array}$ & Bat Batjargal & Dec. 2000 \\
\hline $\begin{array}{l}\text { No. } 350 \text { The Dynamics of Entrepreneurial Networks in a Transitional } \\
\text { Economy: The Case of Russia }\end{array}$ & Bat Batjargal & Dec. 2000 \\
\hline $\begin{array}{l}\text { No. 349a R\&D and Technology Spillovers via FDI: Innovation and } \\
\text { Absorptive Capacity }\end{array}$ & Yuko Kinoshita & Apr. 2001 \\
\hline $\begin{array}{l}\text { No. } 349 \text { R\&D and Technology Spillovers via FDI: Innovation and } \\
\text { Absorptive Capacity }\end{array}$ & Yuko Kinoshita & Nov. 2000 \\
\hline $\begin{array}{l}\text { No. } 348 \text { Microeconomic aspects of Economic Growth in Eastern } \\
\text { Europe and the Former Soviet Union, 1950-2000 }\end{array}$ & Sergei Guriev and Barry W. Ickes & Nov. 2000 \\
\hline $\begin{array}{l}\text { No. } 347 \text { Effective versus Statutory Taxation: Measuring Effective Tax } \\
\text { Administration in Transition Economies }\end{array}$ & $\begin{array}{l}\text { Mark E. Schaffer and Gerard } \\
\text { Turley }\end{array}$ & Nov. 2000 \\
\hline $\begin{array}{l}\text { No. } 346 \text { Objectives and Constraints of Entrepreneurs: Evidence from } \\
\text { Small and Medium Size Enterprises in Russia and Bulgaria }\end{array}$ & $\begin{array}{l}\text { Francesca Pissarides, Miroslav } \\
\text { Singer and Jan Svejnar }\end{array}$ & Oct. 2000 \\
\hline No. 345 Corruption and Anticorruption in the Czech Republic & $\begin{array}{l}\text { Lubomír Lízal and Evžen } \\
\text { Kočenda }\end{array}$ & Oct. 2000 \\
\hline No. 344 The Effects of Direct Foreign Investment on Domestic Firms & Jozef Konings & Oct. 2000 \\
\hline No. 343 On the Identification of Relative Wage Rigidity Dynamics & hani & Oct. 2000 \\
\hline $\begin{array}{l}\text { No. } 342 \text { The Determinants of Foreign Direct Investment in Transition } \\
\text { Economies }\end{array}$ & Alan A. Bevan and Saul Estrin & Oct. 2000 \\
\hline No. 341 The Global Spread of Stock Exchanges, 1980-1998 & Klaus Weber and Gerald F. Davis & Nov. 2000 \\
\hline $\begin{array}{l}\text { No. } 340 \text { The Costs and Benefits of Euro-isation in Central-Eastern } \\
\text { Europe Before or Instead of EMU Membership }\end{array}$ & D. Mario Nuti & Oct. 2000 \\
\hline No. 339 Debt Overhang and Barter in Russia & $\begin{array}{l}\text { Sergei Guriev, Igor Makarov and } \\
\text { Mathilde Maurel }\end{array}$ & Sept. 2000 \\
\hline $\begin{array}{l}\text { No. } 338 \text { Firm Performance and the Political Economy of Corporate } \\
\text { Governance: Survey Evidence for Bulgaria, Hungary, Slovakia and } \\
\text { Slovenia }\end{array}$ & $\begin{array}{l}\text { Patrick Paul Walsh and Ciara } \\
\text { Whela }\end{array}$ & July 2000 \\
\hline No. 337 Investment and Instability & $\begin{array}{l}\text { Nauro F. Campos and Jeffrey B. } \\
\text { Nugent }\end{array}$ & May 2000 \\
\hline $\begin{array}{l}\text { No. } 336 \text { The Evolution of the Insurance Sector in Central and } \\
\text { Eastern Europe and the former Soviet Union }\end{array}$ & Robert B.K. Pye & Aug. 2000 \\
\hline $\begin{array}{l}\text { No. } 335 \text { Institutional Technology and the Chains of Trust: Capital } \\
\text { Markets and Privatization in Russia and the Czech Republic }\end{array}$ & Bruce Kogut and Andrew Spicer & Aug. 2000 \\
\hline No. 334 The Evolution of Market Integration in Russia & $\begin{array}{l}\text { Daniel Berkowitz and David N. } \\
\text { DeJong }\end{array}$ & Aug. 2000 \\
\hline No. 333 Efficiency and Market Share in Hungarian Corporate Sector & László Halpern and Gábor Körösi & July 2000 \\
\hline No. 332 Search-Money-and-Barter Models of Financial Stabilization & $\begin{array}{l}\text { S.I. Boyarchenko and S.Z. } \\
\text { Levendorskii }\end{array}$ & July 2000 \\
\hline $\begin{array}{l}\text { No. } 331 \text { Worker Training in a Restructuring Economy: Evidence from } \\
\text { the Russian Transition }\end{array}$ & $\begin{array}{l}\text { Mark C. Berger, John S. Earle } \\
\text { and Klara Z. Sabirianova }\end{array}$ & Aug. 2000 \\
\hline $\begin{array}{l}\text { No. } 330 \text { Economic Development in Palanpur 1957-1993: A Sort of } \\
\text { Growth }\end{array}$ & Peter Lanjouw & Aug. 2000 \\
\hline
\end{tabular}




\begin{tabular}{|c|c|c|}
\hline $\begin{array}{l}\text { No. } 329 \text { Trust, Organizational Controls, Knowledge Acquisition from } \\
\text { the Foreign Parents, and Performance in Vietnamese International Joint } \\
\text { Ventures }\end{array}$ & $\begin{array}{l}\text { Marjorie A. Lyles, Le Dang } \\
\text { Doanh, and Jeffrey Q. Barden }\end{array}$ & June 2000 \\
\hline $\begin{array}{l}\text { No. } 328 \text { Comparative Advertising in the Global Marketplace: The } \\
\text { Effects of Cultural Orientation on Communication }\end{array}$ & $\begin{array}{l}\text { Zeynep Gürhan-Canli and } \\
\text { Durairaj Maheswaran }\end{array}$ & Aug. 2000 \\
\hline No. 327 Post Privatization Enterprise Restructuring & Morris Bornstein & July 2000 \\
\hline No. 326 Who is Afraid of Political Instability? & $\begin{array}{l}\text { Nauro F. Campos and Jeffrey B. } \\
\text { Nugent }\end{array}$ & July 2000 \\
\hline No. 325 Business Groups, the Financial Market and Modernization & Raja Kali & June 2000 \\
\hline $\begin{array}{l}\text { No. } 324 \text { Restructuring with What Success? A Case Study of Russian } \\
\text { Firms }\end{array}$ & Susan Linz & July 2000 \\
\hline $\begin{array}{l}\text { No. } 323 \text { Priorities and Sequencing in Privatization: Theory and } \\
\text { Evidence from the Czech Republic }\end{array}$ & $\begin{array}{l}\text { Nandini Gupta, John C. Ham and } \\
\text { Jan Svejnar }\end{array}$ & May 2000 \\
\hline $\begin{array}{l}\text { No. } 322 \text { Liquidity, Volatility, and Equity Trading Costs Across } \\
\text { Countries and Over Time }\end{array}$ & $\begin{array}{l}\text { Ian Domowitz, Jack Glen and } \\
\text { Ananth Madhavan }\end{array}$ & Mar. 2000 \\
\hline $\begin{array}{l}\text { No. } 321 \text { Equilibrium Wage Arrears: A Theoretical and Empirical } \\
\text { Analysis of Institutional Lock-In }\end{array}$ & $\begin{array}{l}\text { John S. Earle and Klara Z. } \\
\text { Sabirianova }\end{array}$ & Oct. 2000 \\
\hline No. 320 Rethinking Marketing Programs for Emerging Markets & $\begin{array}{l}\text { Niraj Dawar and Amitava } \\
\text { Chattopadhyay }\end{array}$ & June 2000 \\
\hline $\begin{array}{l}\text { No. } 319 \text { Public Finance and Low Equilibria in Transition Economies: } \\
\text { the Role of Institutions }\end{array}$ & $\begin{array}{l}\text { Daniel Daianu and Radu } \\
\text { Vranceanu }\end{array}$ & June 2000 \\
\hline $\begin{array}{l}\text { No. } 318 \text { Some Econometric Evidence on the Effectiveness of Active } \\
\text { Labour Market Programmes in East Germany }\end{array}$ & $\begin{array}{l}\text { Martin Eichler and Michael } \\
\text { Lechner }\end{array}$ & June 2000 \\
\hline No. 317 A Model of Russia's "Virtual Econc & R.E Ericson and B.W Ickes & May 2000 \\
\hline $\begin{array}{l}\text { No. } 316 \text { Financial Institutions, Financial Contagion, and Financial } \\
\text { Crises }\end{array}$ & $\begin{array}{l}\text { Haizhou Huang and Chenggang } \\
\mathrm{Xu}\end{array}$ & Mar. 2000 \\
\hline $\begin{array}{l}\text { No. } 315 \text { Privatization versus Regulation in Developing Economies: The } \\
\text { Case of West African Banks }\end{array}$ & $\begin{array}{l}\text { Jean Paul Azam, Bruno Biais, and } \\
\text { Magueye Dia }\end{array}$ & Feb. 2000 \\
\hline $\begin{array}{l}\text { No. } 314 \text { Is Life More Risky in the Open? Household Risk-Coping and } \\
\text { the Opening of China's Labor Markets }\end{array}$ & John Giles & Apr. 2000 \\
\hline $\begin{array}{l}\text { No. } 313 \text { Networks, Migration and Investment: Insiders and Outsiders in } \\
\text { Tirupur's Production Cluster }\end{array}$ & $\begin{array}{l}\text { Abhijit Banerjee and Kaivan } \\
\text { Munshi }\end{array}$ & Mar. 2000 \\
\hline $\begin{array}{l}\text { No. } 312 \text { Computational Analysis of the Impact on India of the Uruguay } \\
\text { Round and the Forthcoming WTO Trade Negotiations }\end{array}$ & $\begin{array}{l}\text { Rajesh Chadha, Drusilla K. } \\
\text { Brown, Alan V. Deardorff and } \\
\text { Robert M. Stern }\end{array}$ & Mar. 2000 \\
\hline No. 311 Subsidized Jobs for Unemployed Workers in Slovakia & Jan. C. van Ours & May 2000 \\
\hline No. 310 Determinants of Managerial Pay in the Czech Republic & $\begin{array}{l}\text { Tor Eriksson, Jaromir Gottvald } \\
\text { and Pavel Mrazek }\end{array}$ & May 2000 \\
\hline $\begin{array}{l}\text { No. } 309 \text { The Great Human Capital Reallocation: An Empirical Analysis } \\
\text { of Occupational Mobility in Transitional Russia }\end{array}$ & Klara Z. Sabirianova & Oct. 2000 \\
\hline No. 308 Economic Development, Legality, and the Transplant Effect & $\begin{array}{l}\text { Daniel Berkowitz, Katharina } \\
\text { Pistor, and Jean-Francois Richard }\end{array}$ & Feb. 2000 \\
\hline $\begin{array}{l}\text { No. } 307 \text { Community Participation, Teacher Effort, and Educational } \\
\text { Outcome: The Case of El Salvador's EDUCO Program }\end{array}$ & Yasuyuki Sawada & Nov. 1999 \\
\hline No. 306 Gender Wage Gap and Segregation in Late Transition & Stepan Jurajda & May 2000 \\
\hline $\begin{array}{l}\text { No. } 305 \text { The Gender Pay Gap in the Transition from Communism: } \\
\text { Some Empirical Evidence }\end{array}$ & Andrew Newell and Barry Reilly & May 2000 \\
\hline No. 304 Post-Unification Wage Growth in East Germany & Jennifer Hunt & Nov. 1998 \\
\hline $\begin{array}{l}\text { No. } 303 \text { How Does Privatization Affect Workers? The Case of the } \\
\text { Russian Mass Privatization Program }\end{array}$ & Elizabeth Brainerd & May 2000 \\
\hline $\begin{array}{l}\text { No. } 302 \text { Liability for Past Environmental Contamination and } \\
\text { Privatization }\end{array}$ & Dietrich Earnhart & Mar. 2000 \\
\hline No. 301 Varieties, Jobs and EU Enlargement & $\begin{array}{l}\text { Tito Boeri and Joaquim Oliveira } \\
\text { Martins }\end{array}$ & May 2000 \\
\hline No. 300 Employer Size Effects in Russia & Todd Idson & Apr. 2000 \\
\hline
\end{tabular}




\begin{tabular}{|c|c|c|}
\hline $\begin{array}{l}\text { No. } 299 \text { Information Complements, Substitutes, and Strategic Product } \\
\text { Design }\end{array}$ & $\begin{array}{l}\text { Geoffrey G. Parker and Marshall } \\
\text { W. Van Alstyne }\end{array}$ & Mar. 2000 \\
\hline $\begin{array}{l}\text { No. } 298 \text { Markets, Human Capital, and Inequality: Evidence from Rural } \\
\text { China }\end{array}$ & $\begin{array}{l}\text { Dwayne Benjamin, Loren Brandt, } \\
\text { Paul Glewwe, and Li Guo }\end{array}$ & May 2000 \\
\hline No. 297 Corporate Governance in the Asian Financial Crisis & $\begin{array}{l}\text { Simon Johnson, Peter Boone, } \\
\text { Alasdair Breach, and Eric } \\
\text { Friedman }\end{array}$ & Nov. 1999 \\
\hline No. 296 Competition and Firm Performance: Lessons from Russia & J. David Brown and John S. Earle & Mar. 2000 \\
\hline No. 295 Wage Determination in Russia: An Econometric Investigation & $\begin{array}{l}\text { Peter J. Luke and Mark E. } \\
\text { Schaffer }\end{array}$ & Mar. 2000 \\
\hline $\begin{array}{l}\text { No. } 294 \text { Can Banks Promote Enterprise Restructuring?: Evidence From } \\
\text { a Polish Bank's Experience }\end{array}$ & John P. Bonin and Bozena Leven & Mar. 2000 \\
\hline No. 293 Why do Governments Sell Privatised Companies Abroad? & $\begin{array}{l}\text { Bernardo Bortolotti, Marcella } \\
\text { Fantini and Carlo Scarpa }\end{array}$ & Mar. 2000 \\
\hline $\begin{array}{l}\text { No. } 292 \text { Going Public in Poland: Case-by-Case Privatizations, Mass } \\
\text { Privatization and Private Sector Initial Public Offerings }\end{array}$ & Wolfgang Aussenegg & Dec. 1999 \\
\hline $\begin{array}{l}\text { No. 291 a Institutional Technology and the Chains of Trust: Capital } \\
\text { Markets and Privatization in Russia and the Czech Republic }\end{array}$ & Bruce Kogut and Andrew Spicer & Feb. 2001 \\
\hline $\begin{array}{l}\text { No. } 291 \text { Institutional Technology and the Chains of Trust: Capital } \\
\text { Markets and Privatization in Russia and the Czech Republic }\end{array}$ & Bruce Kogut and Andrew Spicer & Mar. 1999 \\
\hline No. 290 Banking Crises and Bank Rescues: The Effect of Reputation & Jenny Corbett and Janet Mitchell & Jan. 2000 \\
\hline $\begin{array}{l}\text { No. } 289 \text { Do Active Labor Market Policies Help Unemployed Workers to } \\
\text { Find and Keep Regular Jobs? }\end{array}$ & Jan C. van Ours & Feb. 2000 \\
\hline No. 288 Consumption Patterns of the New Elite in Zimbabwe & Russell Belk & Feb. 2000 \\
\hline $\begin{array}{l}\text { No. } 287 \text { Barter in Transition Economies: Competing Explanations } \\
\text { Confront Ukranian Data }\end{array}$ & $\begin{array}{l}\text { Dalia Marin, Daniel Kaufmann } \\
\text { and Bogdan Gorochowskij }\end{array}$ & Jan. 2000 \\
\hline $\begin{array}{l}\text { No. } 286 \text { The Quest for Pension Reform: Poland's Security through } \\
\text { Diversity }\end{array}$ & $\begin{array}{l}\text { Marek Góra and Michael } \\
\text { Rutkowski }\end{array}$ & Jan. 2000 \\
\hline No. 285 Disorganization and Financial Collapse & $\begin{array}{l}\text { Dalia Marin and Monika } \\
\text { Schnitzer }\end{array}$ & Oct. 1999 \\
\hline No. 284 Coordinating Changes in M-form and U-form Organizations & $\begin{array}{l}\text { Yingyi Qian, Gérard Roland and } \\
\text { Chenggang Xu }\end{array}$ & May 1999 \\
\hline $\begin{array}{l}\text { No. } 283 \text { Why Russian Workers Do Not Move: Attachment of Workers } \\
\text { Through In-Kind Payments }\end{array}$ & Guido Friebel and Sergei Guriev & Oct. 1999 \\
\hline No. 282 Lessons From Fiascos in Russian Corporate Governance & $\begin{array}{l}\text { Merritt B. Fox and Michael A. } \\
\text { Heller }\end{array}$ & Oct. 1999 \\
\hline $\begin{array}{l}\text { No. } 281 \text { Income Distribution and Price Controls: Targeting a Social } \\
\text { Safety Net During Economic Transition }\end{array}$ & $\begin{array}{l}\text { Michael Alexeev and James } \\
\text { Leitzel }\end{array}$ & Mar. 1999 \\
\hline $\begin{array}{l}\text { No. 280: Starting Positions, Reform Speed, and Economic Outcomes in } \\
\text { Transitioning Economies }\end{array}$ & William Hallagan and Zhang Jun & Jan. 2000 \\
\hline No. 279 : The Value of Prominent Directors & $\begin{array}{l}\text { Yoshiro Miwa \& J. Mark } \\
\text { Ramseyer }\end{array}$ & Oct. 1999 \\
\hline No. 278: The System & János Kornai & Apr. 1998 \\
\hline $\begin{array}{l}\text { No. 277: The Developmental Consequences of Foreign Direct } \\
\text { Investment in the Transition from Socialism to Capitalism: The } \\
\text { Performance of Foreign Owned Firms in Hungary }\end{array}$ & Lawrence Peter King & Sept. 1999 \\
\hline $\begin{array}{l}\text { No. 276: Stability and Disorder: An Evolutionary Analysis of Russia's } \\
\text { Virtual Economy }\end{array}$ & $\begin{array}{l}\text { Clifford Gaddy and Barry W. } \\
\text { Ickes }\end{array}$ & Nov. 1999 \\
\hline $\begin{array}{l}\text { No. 275: Limiting Government Predation Through Anonymous } \\
\text { Banking: A Theory with Evidence from China. }\end{array}$ & $\begin{array}{l}\text { Chong-En Bai, David D. Li, } \\
\text { Yingyi Qian and Yijiang Wang }\end{array}$ & July 1999 \\
\hline No. 274: Transition with Labour Supply & Tito Boeri & Dec. 1999 \\
\hline $\begin{array}{l}\text { No. 273: Sectoral Restructuring and Labor Mobility: A Comparative } \\
\text { Look at the Czech Republic }\end{array}$ & Vit Sorm and Katherine Terrell & Nov. 1999 \\
\hline $\begin{array}{l}\text { No. 272: Published in: Journal of Comparative Economics "Returns to } \\
\text { Human Capital Under the Communist Wage Grid and During the } \\
\text { Transition to a Market Economy" Vol. 27, pp. 33-60 } 1999 .\end{array}$ & $\begin{array}{l}\text { Daniel Munich, Jan Svejnar and } \\
\text { Katherine Terrell }\end{array}$ & Oct. 1999 \\
\hline
\end{tabular}

